Prepared in cooperation with the Minnesota Pollution Control Agency and St. Cloud State University

Occurrence of Endocrine Active Compounds and Biological Responses in the Mississippi River-Study Design and Data, June-August 2006

Data Series 368

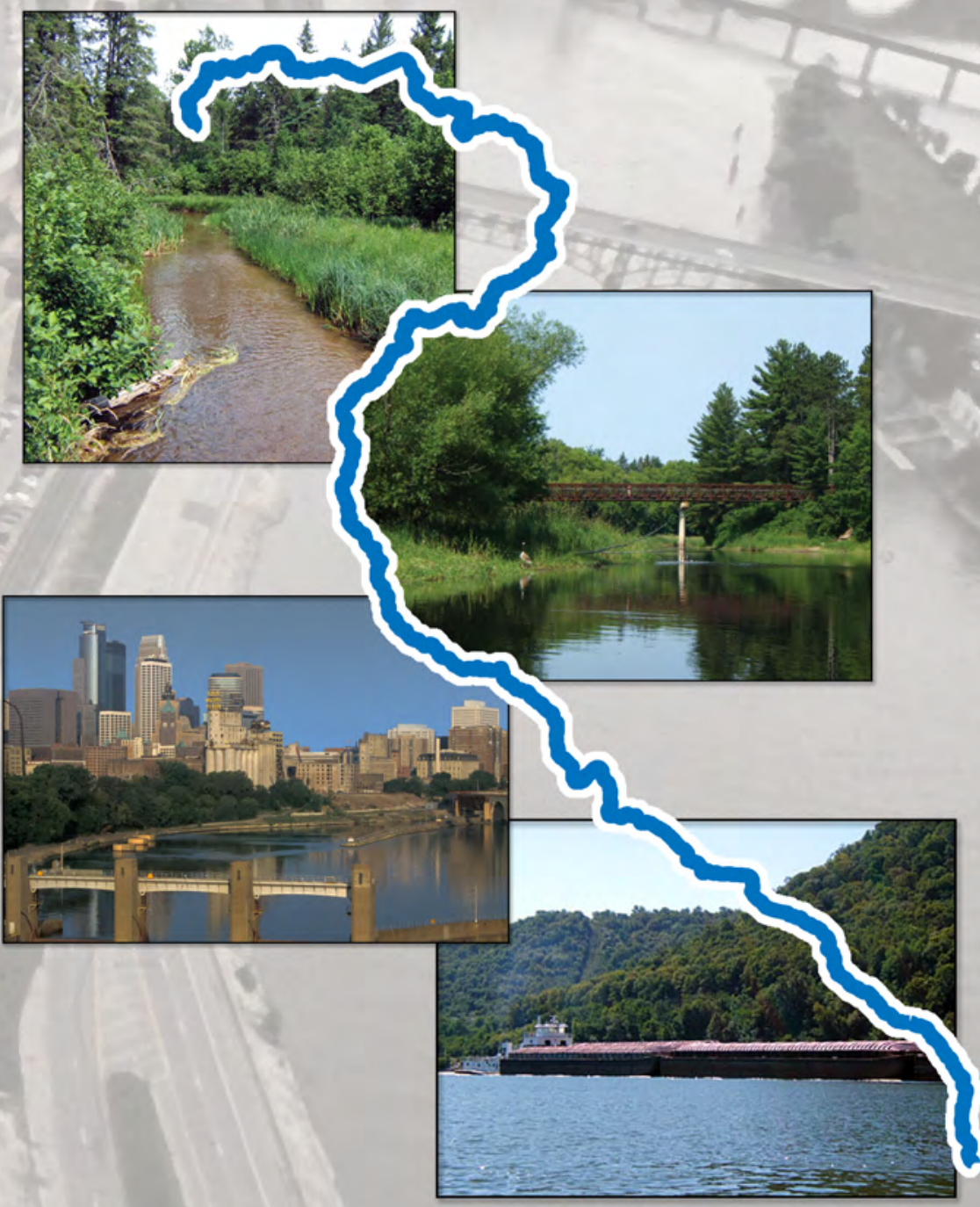


Cover photographs: Top, left: Mississippi River near Lake Itasca, Minnesota, July 2006 (photograph by Kathy Lee, U.S. Geological Survey). Top, right: Mississippi River near Grand Rapids, Minnesota, July 2006 (photograph by John Greene, U.S. Geological Survey). Bottom left: Mississippi River near Minneapolis, Minnesota (photograph by James Stark).

Bottom right: Mississippi River in Lake Pepin above Read's Landing (photograph by Irina Comardicea).

Background photograph: Mississippi River and downtown St. Paul, Minnesota. 


\section{Occurrence of Endocrine Active Compounds and Biological Responses in the Mississippi River-Study Design and Data, June through August 2006}

By Kathy E. Lee, Christine S. Yaeger, Nathan D. Jahns, and Heiko L. Schoenfuss

Prepared in cooperation with the Minnesota Pollution Control Agency and St. Cloud State University

Data Series 368 


\section{U.S. Department of the Interior DIRK KEMPTHORNE, Secretary}

\section{U.S. Geological Survey \\ Mark D. Myers, Director}

\section{U.S. Geological Survey, Reston, Virginia: 2008}

For product and ordering information:

World Wide Web: http://www.usgs.gov/pubprod

Telephone: 1-888-ASK-USGS

For more information on the USGS--the Federal source for science about the Earth, its natural and living resources, natural hazards, and the environment:

World Wide Web: http://www.usgs.gov

Telephone: 1-888-ASK-USGS

Any use of trade, product, or firm names is for descriptive purposes only and does not imply endorsement by the U.S. Government.

Although this report is in the public domain, permission must be secured from the individual copyright owners to reproduce any copyrighted materials contained within this report.

Suggested citation:

Lee, K.E., Yaeger, C.S., Jahns, N.D., and Schoenfuss, H.L., 2008, Occurrence of endocrine active compounds and biological responses in the Mississippi River—study design and data, June through August 2006: U.S. Geological Survey Data Series 368, 27 p. with Appendix. 


\section{Contents}

Abstract
Introduction
Purpose and Scope
Environmental Setting
Acknowledgments
Study Design
Site Selection and Data Collection Methods
Laboratory Methods
Quality Assurance and Control
Fed Sediment
Summary.
Selected References
Appendixes 1-7

\section{Figures}

1-6. Maps showing-

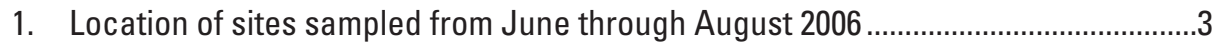

2. Number of wastewater indicator compounds detected in water samples...............17

3. Atrazine detections in water samples ..................................................................18

4. N,N-diethyl-meta-toluamide (DEET) detections in water samples............................19

5. Number of wastewater indicator compounds detected in bed-sediment

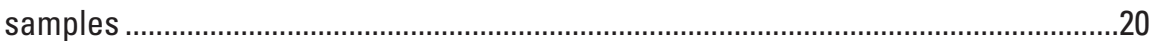

6. Alkylphenol and alkylphenol polyethoxylate detections in bed-sediment samples

\section{Tables}

1. Sites sampled by the U.S. Geological Survey and St. Cloud State University, June through August 2006.

2. Fish species sampled by St. Cloud State University, June through August 2006 .............7

3. Compounds analyzed in water and bed-sediment samples, endocrine disrupting potential, and general compound uses or sources. 


\section{Conversion Factors and Datums}

\begin{tabular}{|c|c|c|}
\hline Multiply & By & To obtain \\
\hline \multicolumn{3}{|c|}{ Length } \\
\hline inch (in.) & 2.54 & centimeter $(\mathrm{cm})$ \\
\hline foot $(\mathrm{ft})$ & 0.3048 & meter $(\mathrm{m})$ \\
\hline mile (mi) & 1.609 & kilometer $(\mathrm{km})$ \\
\hline \multicolumn{3}{|c|}{ Volume } \\
\hline ounce, fluid (fl. oz) & 0.02957 & liter (L) \\
\hline \multicolumn{3}{|c|}{ Flow rate } \\
\hline million gallons per day (Mgal/d) & 0.04381 & cubic meter per second $\left(\mathrm{m}^{3} / \mathrm{s}\right)$ \\
\hline \multicolumn{3}{|c|}{ Mass } \\
\hline ounce, avoirdupois (oz) & 28.35 & $\operatorname{gram}(\mathrm{g})$ \\
\hline
\end{tabular}

Temperature in degrees Celsius $\left({ }^{\circ} \mathrm{C}\right)$ may be converted to degrees Fahrenheit $\left({ }^{\circ} \mathrm{F}\right)$ as follows:

$$
{ }^{\circ} \mathrm{F}=\left(1.8 x^{\circ} \mathrm{C}\right)+32
$$

Temperature in degrees Fahrenheit $\left({ }^{\circ} \mathrm{F}\right)$ may be converted to degrees Celsius $\left({ }^{\circ} \mathrm{C}\right)$ as follows:

$$
{ }^{\circ} \mathrm{C}=\left({ }^{\circ} \mathrm{F}-32\right) / 1.8
$$

Vertical coordinate information is referenced to the North American Vertical Datum of 1988 (NAVD 88).

Horizontal coordinate information is referenced to the North American Datum of 1983 (NAD 83)

Specific conductance is given in microsiemens per centimeter at 25 degrees Celsius $(\mu \mathrm{S} / \mathrm{cm}$ at $\left.25^{\circ} \mathrm{C}\right)$.

Concentrations of chemical constituents in water are given either in milligrams per liter (mg/L) or micrograms per liter $(\mu \mathrm{g} / \mathrm{L})$. 


\section{Abbreviations and Acronyms}

\begin{tabular}{|c|c|}
\hline$\mu \mathrm{g} / \mathrm{L}$ & microgram per liter \\
\hline$\mu \mathrm{g} / \mathrm{mL}$ & microgram per milliliter \\
\hline$\mu \mathrm{g} / \mathrm{kg}$ & microgram per kilogram \\
\hline ASE & accelerated solvent extraction \\
\hline AP & alkylphenol \\
\hline APEC & alkylphenol ethoxycarboxylate \\
\hline APEO & alkylphenol polyethoxylate \\
\hline AP1E0 & alkylphenol mono-ethoxylate \\
\hline CCV & continuing calibration verification \\
\hline DEET & $\mathrm{N}, \mathrm{N}$-diethyl-meta-toluamide \\
\hline EAC & endocrine active compound \\
\hline ELISA & enzyme-linked immunosorbent assay \\
\hline GIS & geographic information system \\
\hline GSI & gonadosomatic index \\
\hline HНCB & hexahydrohexamethylcyclopentabenzopyran \\
\hline HSI & hepatosomatic index \\
\hline MDL & method detection limit \\
\hline MPCA & Minnesota Pollution Control Agency \\
\hline MRL & minimum reporting level \\
\hline NP1E0 & 4-nonylphenol monoethoxylate \\
\hline NP2EO & 4-nonylphenol diethoxylate \\
\hline NPEO & nonylphenolpolyethoxylate \\
\hline NWOL & National Water Quality Laboratory \\
\hline OP1EO & 4-octylphenol monoethoxylate \\
\hline OP2EO & 4-octylphenol diethoxylate \\
\hline OPEO & octylphenol polyethoxylate \\
\hline RPD & relative percent difference \\
\hline SCSU & St. Cloud State University \\
\hline SPE & solid-phase extraction \\
\hline TCMA & Twin Cities (Minneapolis/St. Paul) Metropolitan Area \\
\hline USEPA & U.S. Environmental Protection Agency \\
\hline USGS & U.S. Geological Survey \\
\hline WWTP & wastewater treatment plant \\
\hline
\end{tabular}





\title{
Occurrence of Endocrine Active Compounds and Biological Responses in the Mississippi River- Study Design and Data, June through August 2006
}

\author{
By Kathy E. Lee', Christine S. Yaeger', Nathan D. Jahns², and Heiko L. Schoenfuss ${ }^{2}$
}

\section{Abstract}

Concern that selected chemicals in the environment may act as endocrine active compounds in aquatic ecosystems is widespread; however, few studies have examined the occurrence of endocrine active compounds and identified biological markers of endocrine disruption such as intersex occurrence in fish longitudinally in a river system. This report presents environmental data collected and analyzed by the U.S. Geological Survey, Minnesota Pollution Control Agency, and St. Cloud State University as part of an integrated biological and chemical study of endocrine disruption in fish in the Mississippi River. Data were collected from water, bed sediment, and fish at 43 sites along the river from the headwaters at Lake Itasca to 14 miles downstream from Brownsville, Minnesota, during June through August 2006.

Twenty-four individual compounds were detected in water samples, with cholesterol, atrazine, N,N-diethyl-metatoluamide, metolachlor, and hexahydrohexamethylcyclopentabenzopyran detected most frequently (in at least 10 percent of the samples). The number of compounds detected in water per site ranged from 0 to 8 .

Forty individual compounds were detected in bed-sediment samples. The most commonly detected compounds (in at least 50 percent of the samples) were indole, beta-sitosterol, cholesterol, beta-stigmastanol, 3-methyl-1H-indole, p-cresol, pyrene, phenol, fluoranthene, 3-beta coprostanol, benzo[a] pyrene, acetophenone, and 2,6-dimethylnaphthalene. The total number of detections in bed sediment (at a site) ranged from 3 to 31 . The compounds NP1EO, NP2EO, and 4-nonylphenol were detected in greater than 10 percent of the samples.

Most (80 percent) female fish collected had measurable concentrations of vitellogenin. Vitellogenin also was detected in 62, 63, and 33 percent of male carp, smallmouth bass, and redhorse, respectively. The one male walleye sample plasma sample analyzed had a vitellogenin detection. Vitellogenin concentrations were lower in male fish (not detected to 10.80

${ }^{1}$ U.S. Geological Survey

${ }^{2}$ St. Cloud State University micrograms per milliliter) than female fish (0.04 to 248,079 micrograms per milliliter). Gonadosomatic Index values ranged from 0.02 to 7.49 percent among all male fish and were greater for male carp than for the other three species. No intersex (oocytes present in testes tissue) was found in any male fish sampled.

\section{Introduction}

Concern that selected chemicals in aquatic environments may act as endocrine active compounds (EACs) in aquatic ecosystems is widespread (Colburn and Clement, 1992; Ankley and others, 1998; Kime, 1998). EACs interfere with the natural regulation of endocrine systems by either mimicking or blocking the function of natural hormones (Kime, 1998; National Research Council, 1999). This interference commonly is referred to as endocrine disruption. Although factors contributing to endocrine disruption in fish are complex, laboratory studies have confirmed that exogenous hormones and alkylphenols (a class of surfactants that includes nonylphenol) affect the endocrine systems of fish through biochemical, structural, and behavioral mechanisms (Bistodeau and others, 2006; Barber and others, 2007). Wastewater treatment plant (WWTP) effluent has been identified as a primary pathway of hormones and alkylphenols to the aquatic environment (Desbrow and others, 1998; Ternes and others, 1999; Johnson and Sumpter, 2001). In response to standard toxicity laboratory studies, the U.S. Environmental Protection Agency (USEPA) established final chronic aquatic-life criteria for nonylphenol that are the basis for states and tribes to adopt enforceable standards. The standard is based on a 4-day average concentration not to exceed 6.6 micrograms per liter $(\mu \mathrm{g} / \mathrm{L})$ in lakes and streams for the protection of aquatic life (U.S. Environmental Protection Agency, 2005a).

Endocrine disruption indications in fish have been documented in Minnesota in the effluent channel of the Minneapolis/St. Paul metropolitan WWTP (the largest facility of its kind that discharges to the Upper Mississippi River in Minnesota). Indicators of exposure to EACs include vitellogenin induc- 
tion in male carp (Cyprinus carpio) and walleye (Stizostedion vitreum) (Folmar and others, 1996, 2001; Lee and others, 2000). Intersex characteristics also have been documented in smallmouth bass (Micropterus dolomieu) at eight sites along the Mississippi River (hereinafter referred to as the river), from the upper reaches of the river near Brainerd, Minnesota, downstream to Lake Pepin (Lee and Blazer, 2005); however, Lee and Blazer (2005) did not attempt to identify factors correlated with intersex occurrence in fish.

Because little integrated information is available about endocrine disruption and causative factors in field studies, the U.S. Geological Survey (USGS), in cooperation with the Minnesota Pollution Control Agency (MPCA) and St. Cloud State University (SCSU), initiated an integrated biological and chemical study of the river in Minnesota to build on previous research. Objectives of the study were to collect water, bed sediment, and fish at 43 sites along the river from its source at Lake Itasca to Brownsville from June through August 2006 (fig. 1). The study was designed to identify patterns of occurrence and distribution of selected organic chemicals including EACs and to relate those patterns to intersex characteristics and other biomarkers of endocrine disruption in four species of fish. The study provides information to compare with previous studies measuring intersex occurrence in fish in the river and helps define the spatial distribution of endocrine disruption in the river. Data from the study support evaluations of Minnesota streams relative to the USEPA criteria for nonylphenol through an improved understanding of endocrine disruption and potential sources of EACs in water and bed sediment. Information from the study also is being used by the MPCA to inform policy makers and the public about the need to protect rivers from emerging threats to aquatic organisms.

\section{Purpose and Scope}

This report presents the study design, environmental data, and quality assurance/quality control data for the integrated biological and chemical study of endocrine disruption in fish in the Mississippi River. Monitoring data for EACs and biological responses were collected and analyzed by the USGS, MPCA, and SCSU from 43 sites along the river from the headwaters at Lake Itasca to 14 miles downstream from Brownsville, Minnesota, from June through August 2006 (fig. 1). The goal was to collect samples of all media (water, bed sediment, and fish) from all sites; however, site access and the absence of fish at a site precluded sample collection of all media from all sites. All sample media were collected from 38 common sites. Water and bed sediment were collected solely from three sites, and fish were collected solely from two sites (table 1).

\section{Environmental Setting}

The Mississippi River flows southward in Minnesota from its source at Lake Itasca, in northern Minnesota, to the Minnesota/Iowa border. Along this reach, the river flows though glacial moraines and outwash plains (Stark and others, 1996). Land use and land cover in the basin can be categorized into three general zones: an agricultural zone across the southwestern one-third of the basin; a forested zone across the northeastern one-third; and a transitional zone between these areas. Although urban land accounts for a small percentage of land use, it is heavily concentrated in the Twin Cities (Minneapolis and St. Paul) Metropolitan Area (TCMA) through which the Mississippi, Minnesota, and St. Croix Rivers flow (Stark and others, 1996). The Mississippi River has three major tributaries along the reach that include the Minnesota, St. Croix, and Chippewa Rivers. Each tributary has its own diverse setting and conditions as a result of natural and anthropogenic factors. Dominant factors include land use and land cover, climate, hydrology, geology, soils, water use, and water management.

Surface runoff and streamflow in the river are affected by climatic variations in temperature, precipitation, and evaporation across the basin and by season. The basin has a wide variety of weather patterns in four distinct seasons. Average air temperature ranges from $38^{\circ} \mathrm{F}$ in the north to $43{ }^{\circ} \mathrm{F}$ in the south (Stark and others 1996; Minnesota Pollution Control Agency, 2000). Average annual precipitation ranges from about 24 inches (in.) in the upper basin to $30 \mathrm{in.}$ in the southeastern part of the basin (Stark and others 1996; Minnesota Pollution Control Agency, 2000). Streamflow is greatest in spring and early summer as a result of melting snow, rains falling on melting snow, or intense rains falling on saturated or frozen soils.

Water quality in the river varies along the river's length in response to natural and anthropogenic factors. Surface runoff from intensive row-crop agriculture and urban land use contributes sediment, nutrients, pesticides, trace elements, and other industrial chemicals to streams (Stark and others, 1996). Concentrations of nutrients, suspended sediment, and pesticides in the river increase downstream from the confluence with the Minnesota River, and then decrease slightly downstream from the confluence with the St. Croix River because of dilution from its waters. The primary contributor of suspended sediment to the Mississippi River is from the Minnesota River (Payne, 1994). Concentrations of cadmium, lead, and mercury generally are greatest in bed-sediment samples within or immediately downstream from the TCMA (Kroening and others, 2000; Wiener and others, 1984).

Water use and the disposal of wastewater also affect river quantity and quality. Most water used is returned to the river as wastewater after treatment. The St. Paul Metropolitan WWTP is the largest point-source discharge to the Mississippi River within the study area, discharging 250 million gallons per day (mgal/day) to the river (Barber and others, 2007). Numerous 


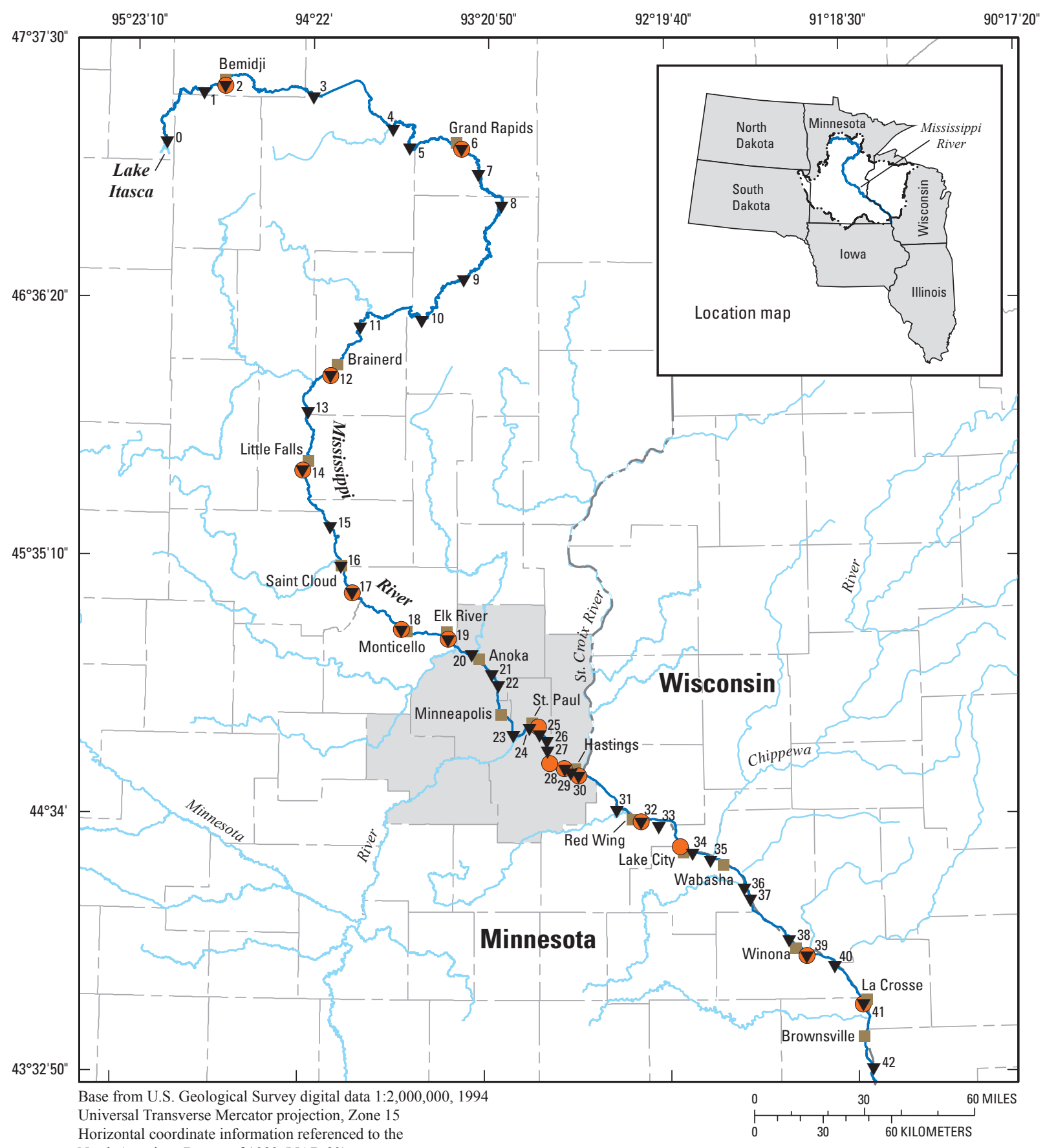

EXPLANATION

Minneapolis/St. Paul metropolitan area

$\nabla^{0}$ Sampling site and identifier

Municipal wastewater-treatment plant-Average design flows greater than or equal to one million gallons per day

Figure 1. Location of sites sampled from June through August 2006. 


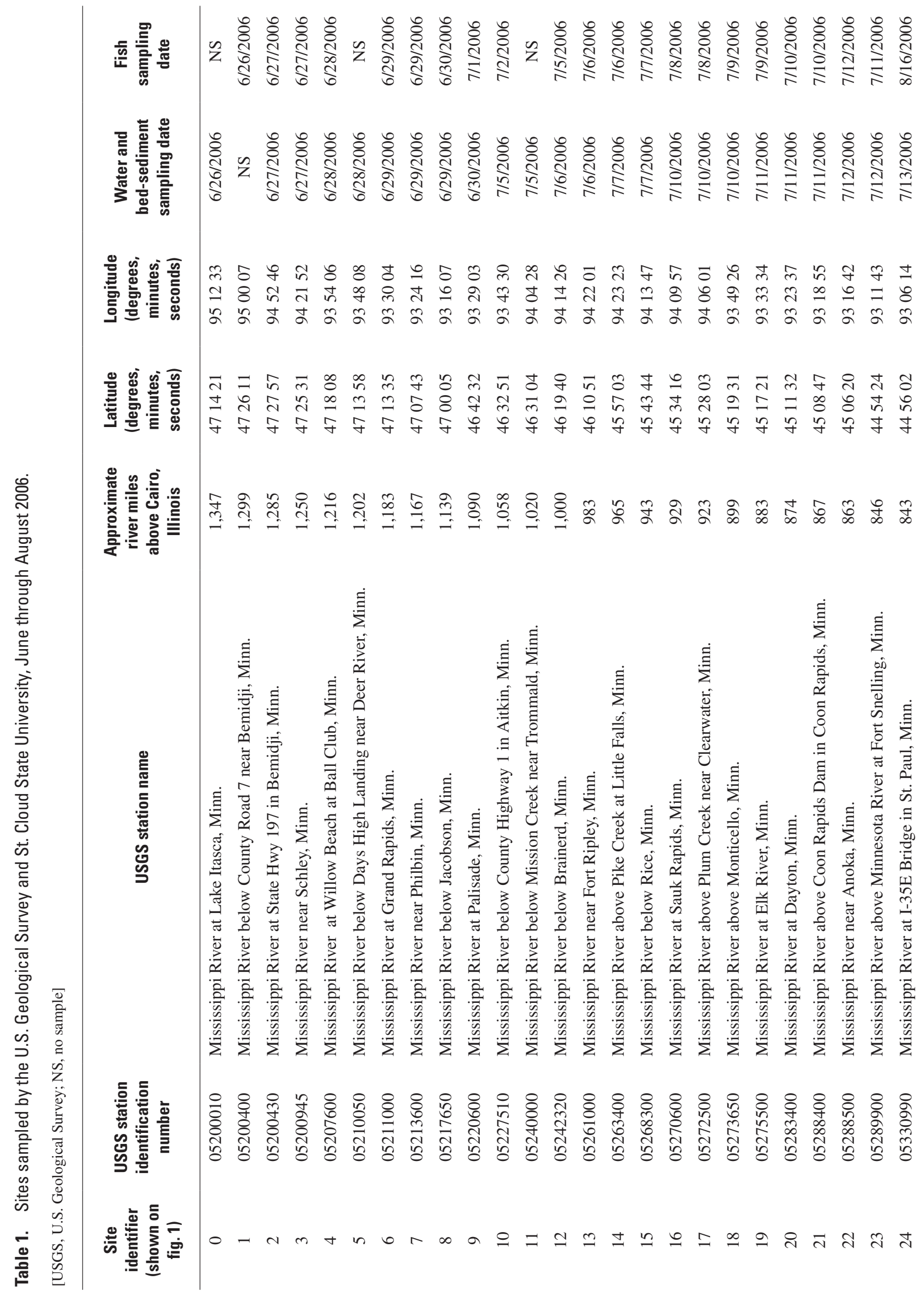




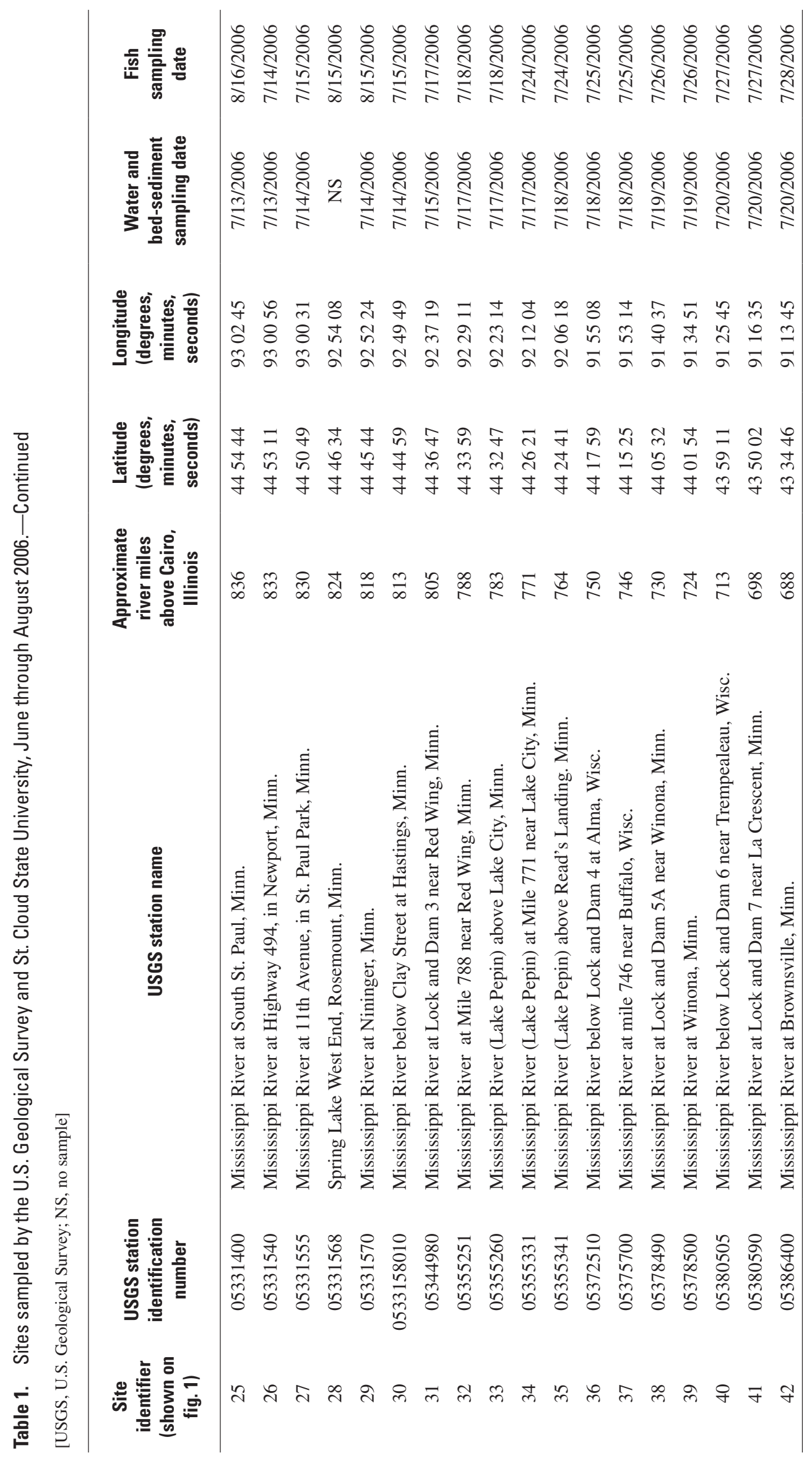


other major WWTPs discharge directly to the Mississippi River in Minnesota including those in Bemidji, Grand Rapids, Brainerd, Little Falls, St. Cloud, Monticello, Elk River, Rosemount, Cottage Grove, Hastings, Redwing, Lake City, and Winona.

Biological communities in the river are affected by chemical and physical conditions. Fish communities in the river downstream from the TCMA contain more species than the Mississippi River upstream from the TCMA because of a waterfall and dam at St. Anthony Falls that forms a fish migration barrier (Underhill, 1989). Other differences exist among segments of the river. The upper part of the river has fish species that thrive in colder waters, because of inflow from the cooler waters from the tributaries. Fish communities in these reaches are dominated by species like redhorse, suckers, and smallmouth bass. Further downstream, particularly downstream from the TCMA, the fish community consists of more warm-water-tolerant species like catfish, buffalo fish, freshwater drum, carpsuckers, and shiners (Goldstein and others, 1999).

Fish communities are affected by numerous anthropogenic activities including loss of riparian habitat, reduction in fish populations, loss of habitat for bottom-dwelling organisms, eutrophication, and introduction of contaminants. Changes in habitat of the river have resulted from the construction of locks and dams, dredging to maintain navigation channels, modifications to stream morphology, and changes in land use. Introduction of contaminants such as EACs can adversely affect the health of aquatic biota and may bioconcentrate in aquatic organisms and bioaccumulate through the food chain.

\section{Acknowledgments}

The authors acknowledge Angela Preimesberger, Gary Kimball, and Marvin Hora from the MPCA; numerous students from SCSU; Jack Enblom, Jack Wingate, and many other MDNR personnel; and the personnel from numerous wastewater treatment facilities for their cooperation on this study. The authors acknowledge all the personnel from each agency that made this unique and challenging study possible. The authors also acknowledge Steve Bartell for vitellogenin analyses.

\section{Study Design}

The USGS cooperated with the MPCA and SCSU on this study. The study was designed to identify patterns of occurrence and distribution of selected organic chemicals including EACs, and to relate those patterns to intersex characteristics and other biomarkers of endocrine disruption in four species of fish. This section of the report describes site selection and data-collection methods, laboratory methods, and quality assurance and control.

\section{Site Selection and Data Collection Methods}

An interagency effort using a geographic information system (GIS) approach was used to select sampling sites. Sites were selected where previous biological and chemical data had been collected upstream and downstream from point-source discharges, major changes in land use (from forested to agricultural and urban land use) had occurred, and where major tributary inflows were present. Based on these criteria, 43 sites were selected and sampled from June 25 through August 16, 2006 (fig. 1, table 1). USGS personnel collected and analyzed water and sediment samples; SCSU staff collected and analyzed fish samples (table 2).

Water samples were collected from 41 of the 43 sites (table 1) using established USGS techniques (U.S. Geological Survey, 2003). Samples were collected by wading techniques or from boats or bridges, depending on stream size and streamflow conditions. To ensure that samples collected were representative of water flowing in the entire stream cross section, samples were collected with a depth-integrating sampler from 5 to10 equally-spaced verticals. In backwater locations that were more lentic in nature, samples were collected with a depth-integrating sampler from 5 to 10 locations within 328 feet (ft) of the targeted sampling location. Following sample collection, whole water samples were composited into a glass or Teflon container and chilled before processing. Chilled samples were processed within 1 to 2 hours of collection before shipping to the USGS National Water Quality Laboratory (NWQL) in Lakewood, Colorado.

Bed-sediment samples were collected from 41 of the 43 sites (table 1) using established USGS protocols (U.S. Geological Survey, 2003). Samples were collected from the top 20 $\mathrm{cm}$ of bed sediment at 5-10 depositional areas at each sampling location with a stainless steel Eckman dredge sampler or other stainless steel sampling equipment. The bed-sediment sample was discarded if it contained a large amount of vegetation or appeared to be disturbed. Bed-sediment samples were transferred to a glass container and homogenized for 5 minutes. After homogenization, about 3.5 to 7.5 ounces (oz) of unsieved wet material was placed in wide-mouth glass containers, chilled, and sent to the NWQL.

To minimize contamination of samples, use of personal-care items (such as insect repellent, sunscreen, cologne, aftershave, and perfume) were avoided by personnel collecting and processing samples. Caffeinated and tobacco products were not consumed or handled by sample collectors during (or immediately before) collection or processing of samples. Additionally, sampling and processing equipment was cleaned and stored according to rigorous cleaning protocols for collection of organic compounds (U.S. Geological Survey, 2003). 


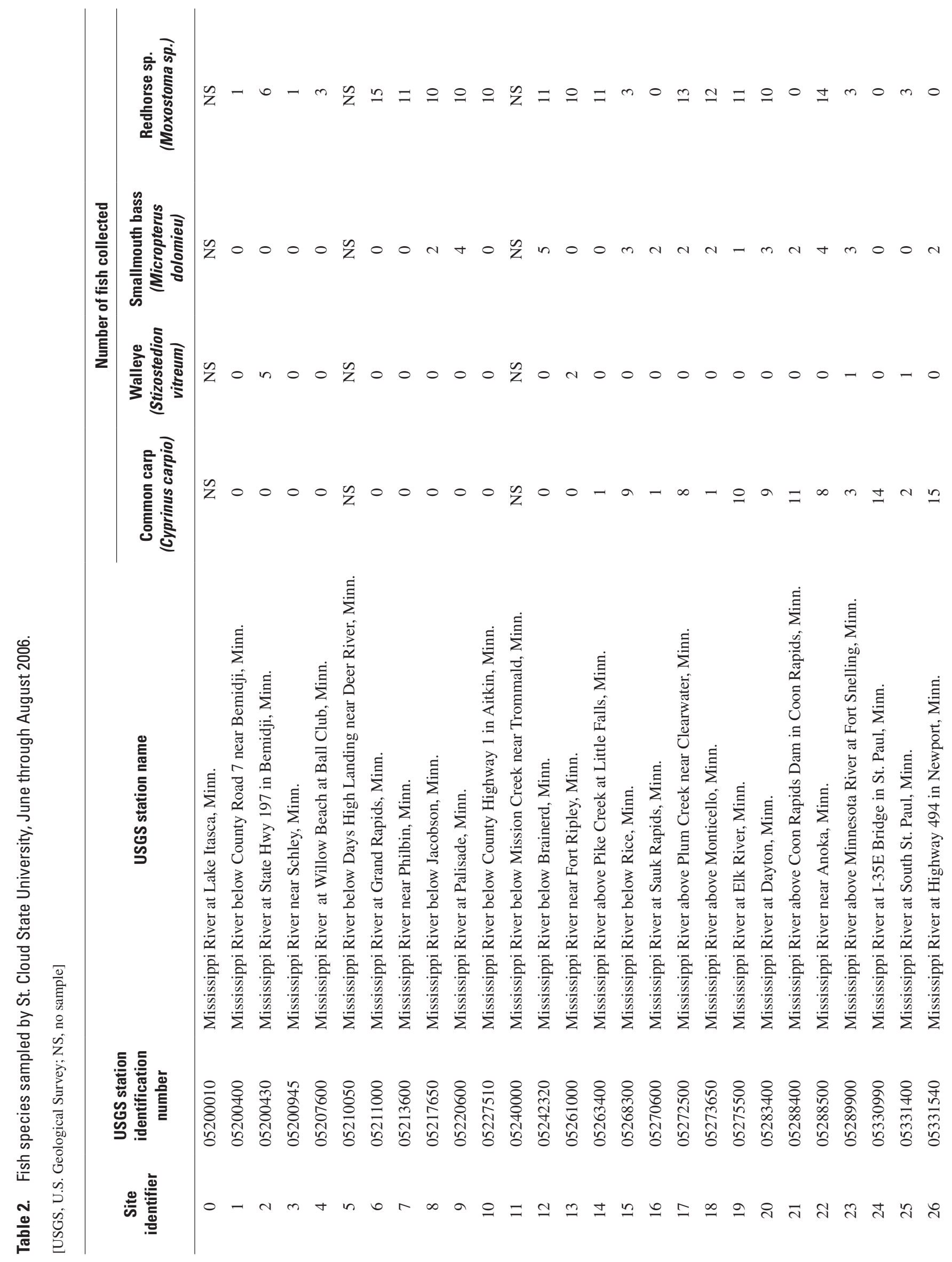




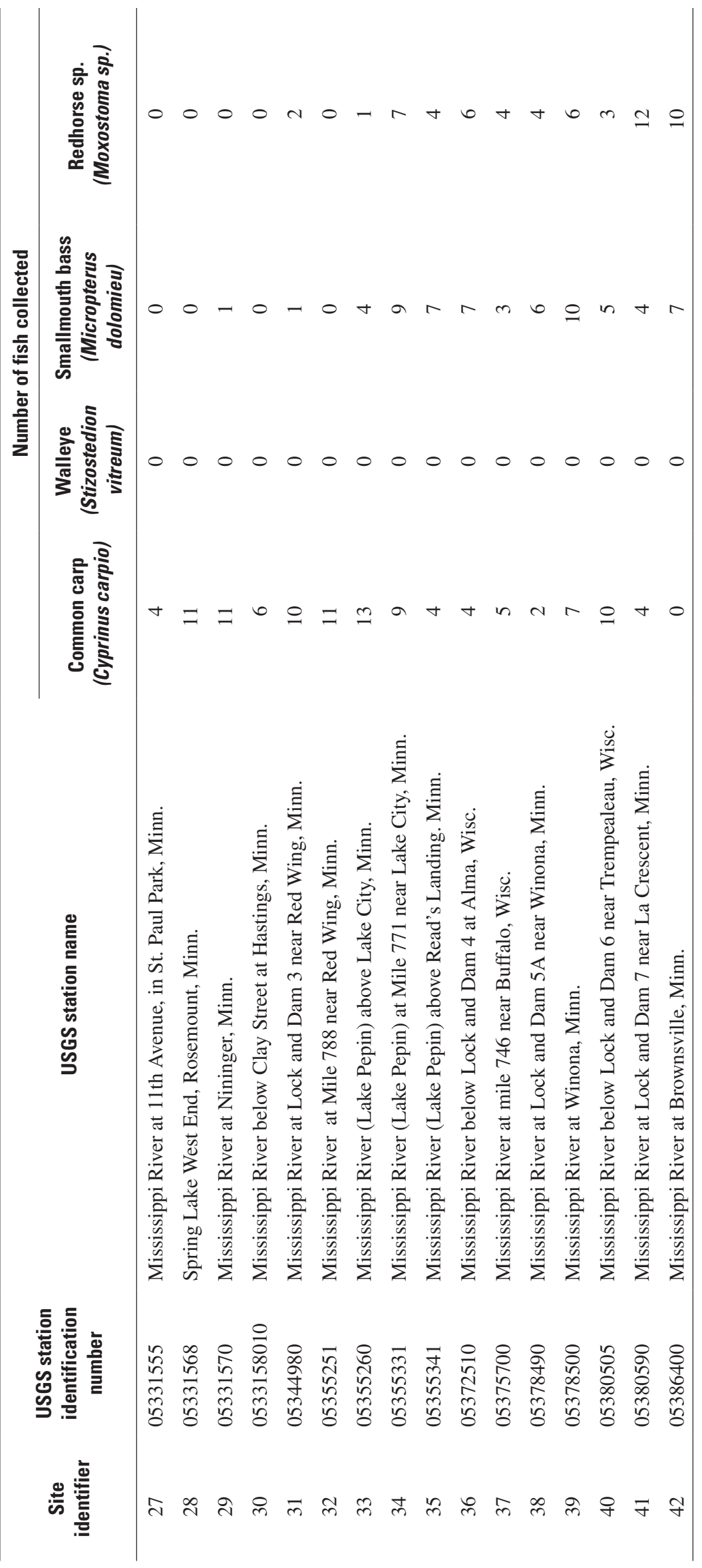


Physical water-quality measurements (dissolved oxygen, $\mathrm{pH}$, specific conductance, and water temperature) were made using a submersible data sonde. The sonde was calibrated according to U.S. Geological Survey (2003) and manufacturer's specifications before and after sampling to ensure accurate measurements.

Walleye (Stizostedion vitreum), smallmouth bass (Micropterus dolomieu), redhorse species (Moxostoma sp.), and common carp (Cyprinus carpio) were targeted for collection (table 2). Fish were collected from boats using electrofishing techniques from 38 of the 43 sites. Each fish collected was placed into a tub containing 2-percent clove oil to anesthetize the fish. Once sedated, 3 to 5 milliliters $(\mathrm{mL})$ of blood was drawn from the caudal vasculature and transferred into a hematocrit tube that was stored on wet ice. The fish was then sacrificed, and measurements were recorded for the fish's weight, total and standard lengths, as well as weights of extirpated livers and testis. Gonadosomatic indexes (GSIs) were calculated as [gonad weight $(\mathrm{g}) /$ body weight $(\mathrm{g})]$ x 100 (Allen and others, 1999). Hepatosomatic indexes (HSIs) were calculated as [liver weight (g)/total body weight (g)] x 100 (Allen and others, 1999).

Several testis samples were collected for histological analysis, and placed into histological cassettes. In male fish, both testes were removed and a representative sample from the anterior, middle, and posterior section of each testis was collected, marked with ink for later identification, and placed into a histological cassette. Two histological cassettes were prepared from each male fish (left testis and right testis). If gravid ovaries were present in the abdominal cavity, the sex was noted on the data sheets as female, but no attempt was made to weigh or collect these tissues for later histological analysis. The rationale for the exclusion of female reproductive tissue was that a gravid female ovary was too fragile to be removed intact and that histological analysis would not yield any further information. All histological cassettes were then placed into a site-specific container with 4 percent formalin. During the collection, an effort was made to return collected fish samples (blood and testis) to the laboratory within 15 hours but not more than 36 hours, from collection time. All specimens were maintained on ice until they could be processed according to analysis needs in the laboratory.

\section{Laboratory Methods}

Water samples were analyzed at the U.S. Geological Survey National Water-Quality Laboratory (NWQL) in Denver, Colorado (Zaugg and others, 2006) for 68 organic compounds (table 3 ) typically present in domestic and industrial wastewater and nonpoint sources. The analytical method focuses on the determination of compounds that are indicators of wastewater or have endocrine-disrupting potential in whole water samples. These compounds include the alkylphenol ethoxylate nonionic surfactants, food additives, fragrances, antioxidants, flame retardants, plasticizers, industrial solvents, disinfectants, fecal sterols, polycyclic aromatic hydrocarbons, and high-use domestic pesticides. Wastewater compounds in whole-water samples were extracted using continuous liquid-liquid extractors and methylene chloride solvent, and then determined by capillary-column gas chromatography/mass spectrometry. Samples were preserved by adding $2.1 \mathrm{oz}$ of sodium chloride and stored at $39.2{ }^{\circ} \mathrm{F}$. The holding-time limit before sample extraction was 14 days from the date of collection.

Bed sediment was analyzed for 57 compounds (table 3) at the USGS NWQL using methods described in Burkhardt and others (2006). The chemicals analyzed are similar to those analyzed in water samples with the exception of 11 compounds that did not meet quality-assurance criteria during method development or had a low probability of partitioning to bed sediment (Burkhardt and others, 2006). The method uses accelerated solvent extraction (ASE), Soxhlet extration, and solid-phase extraction (SPE) for sample preparation, with analysis by capillary-column gas chromatography/mass spectrometry. The method identifies and quantifies individual compounds using retention times and spectral matches, along with standard calibration curves. Samples were preserved by freezing to $-4{ }^{\circ} \mathrm{F}$. The USGS NWQL has established a 1-year sample-holding time limit (before sample extraction) from the date of sample collection (if the sample is kept at $-4{ }^{\circ} \mathrm{F}$ ) until a statistically accepted method can be used to determine the effectiveness of the sample-freezing procedure.

The alkylphenol polyethoxylates (APEOs), one class of compounds analyzed, are branched-chain nonionic surfactants that consist of the nonylphenol polyethoxylates (NPEOs) and the octylphenol polyethoxylates (OPEOs) (Zaugg and others, 2006). The alkylphenol mono-ethoxylates (AP1EOs) are represented in the analytical method by 4-octylphenol monoethoxylate (OP1EO) and 4-nonylphenol monoethoxylate (NP1EO) (total, resulting from addition of several isomers). The alkylphenol di-ethoxylates are represented by 4-octylphenol diethoxylate (OP2EO) and 4-nonylphenol diethoxylate (NP2EO) (total). The degradation of APEOs in the environment can result in the formation of alkylphenols (APs) and alkylphenol ethoxycarboxylates (APECs). The APs are represented in the method by 4-cumylphenol, 4- $n$-octylphenol, 4-nonylphenol (total), and 4-tert-octylphenol. The volatility and availability of reference standards for APEOs limit the method to the determination of OP1EO, OP2EO, NP1EO (total), and NP2EO (total), even though APEOs typically might contain as many as about 20 ethoxy-units; however, most of the APEOs present in the environment after degradation contain less than four ethoxy-units (Zaugg and others, 2006). The laboratory method used in this report did not include APECs.

Fish tissues were analyzed at the SCSU Aquatic Toxicology Laboratory following established and previously published protocols (Bistodeau and others, 2006; Barber and others, 2007; Schoenfuss and others, 2008) and guidelines established by the U.S. Environmental Protection Agency (2006). 


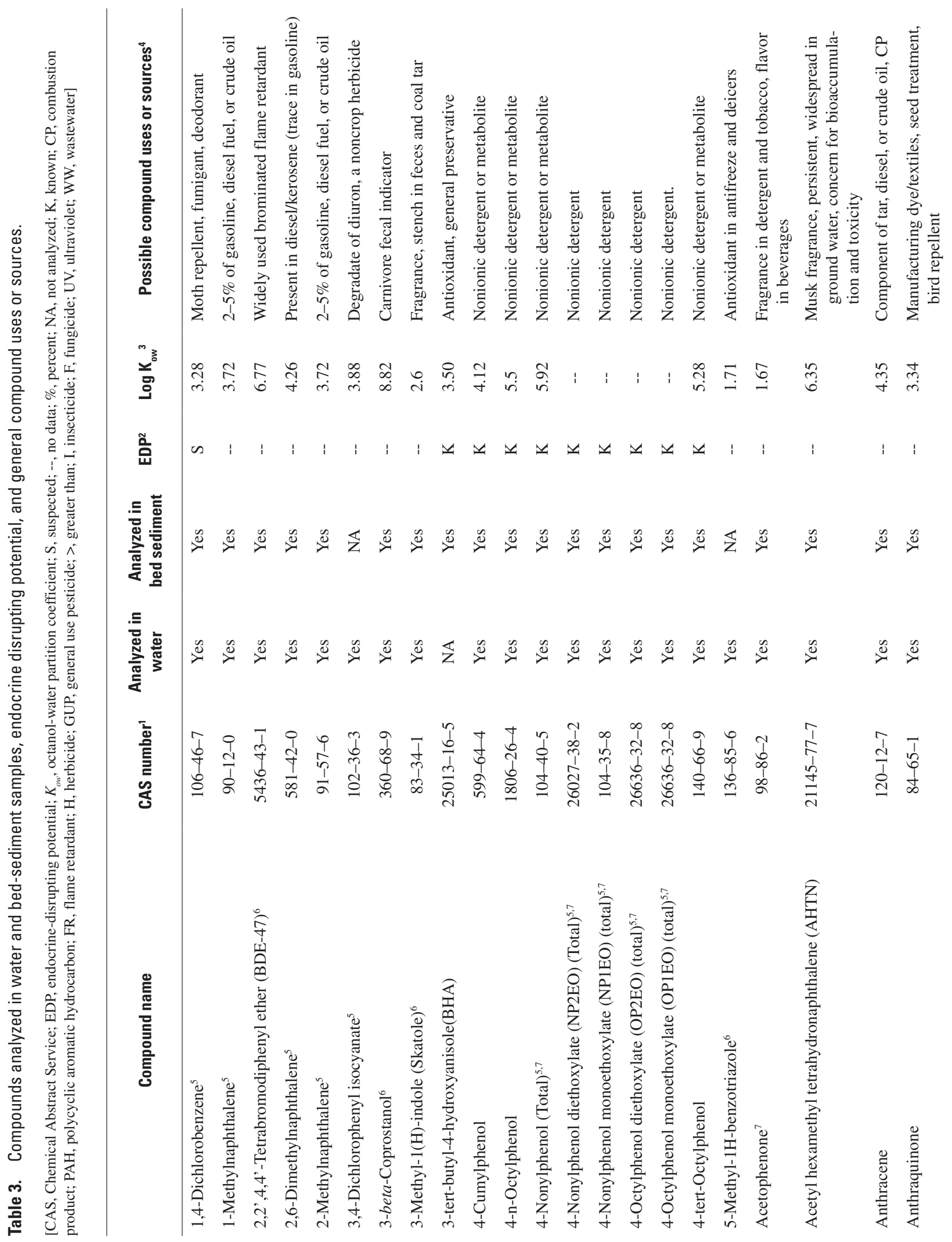




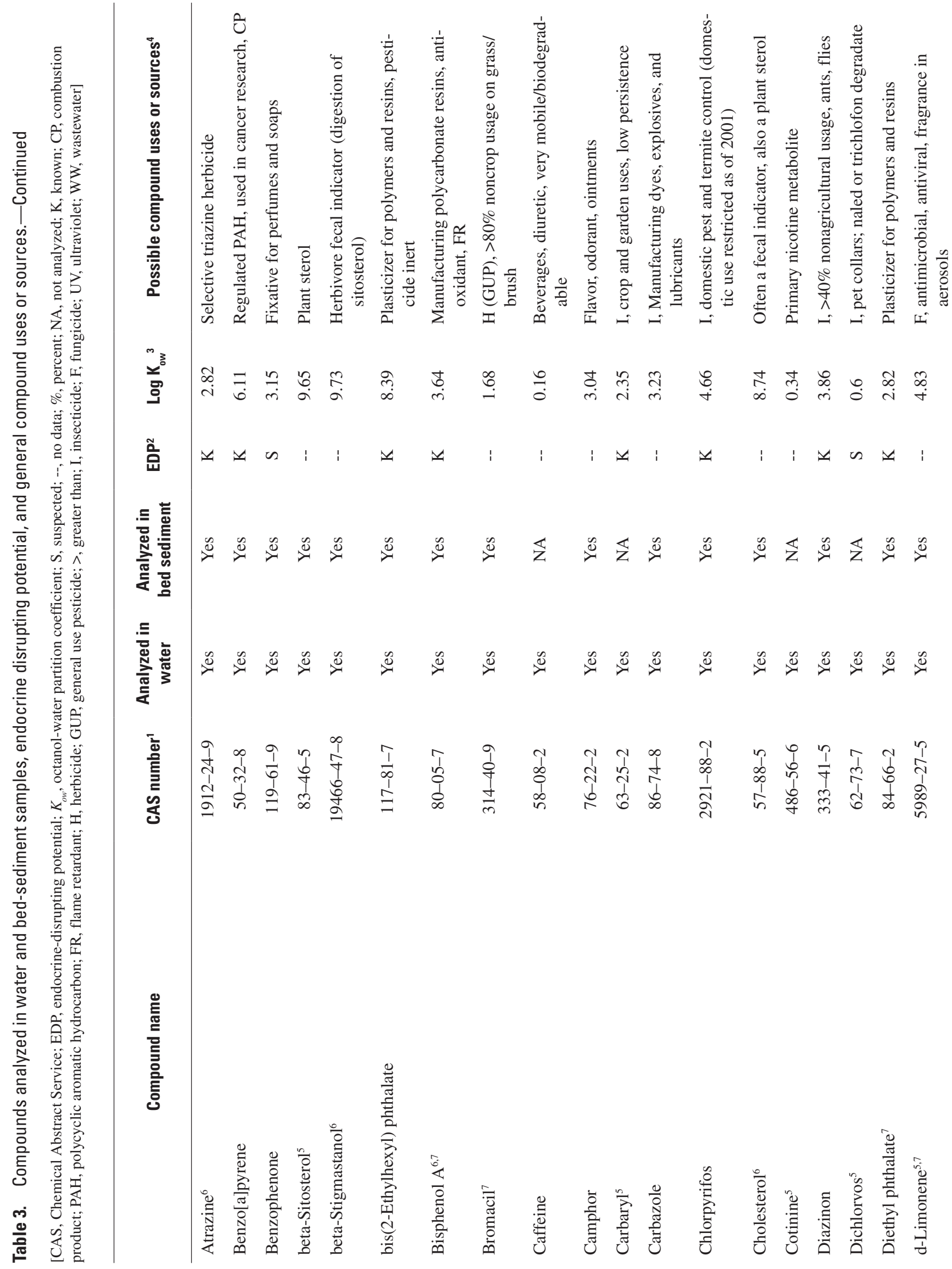




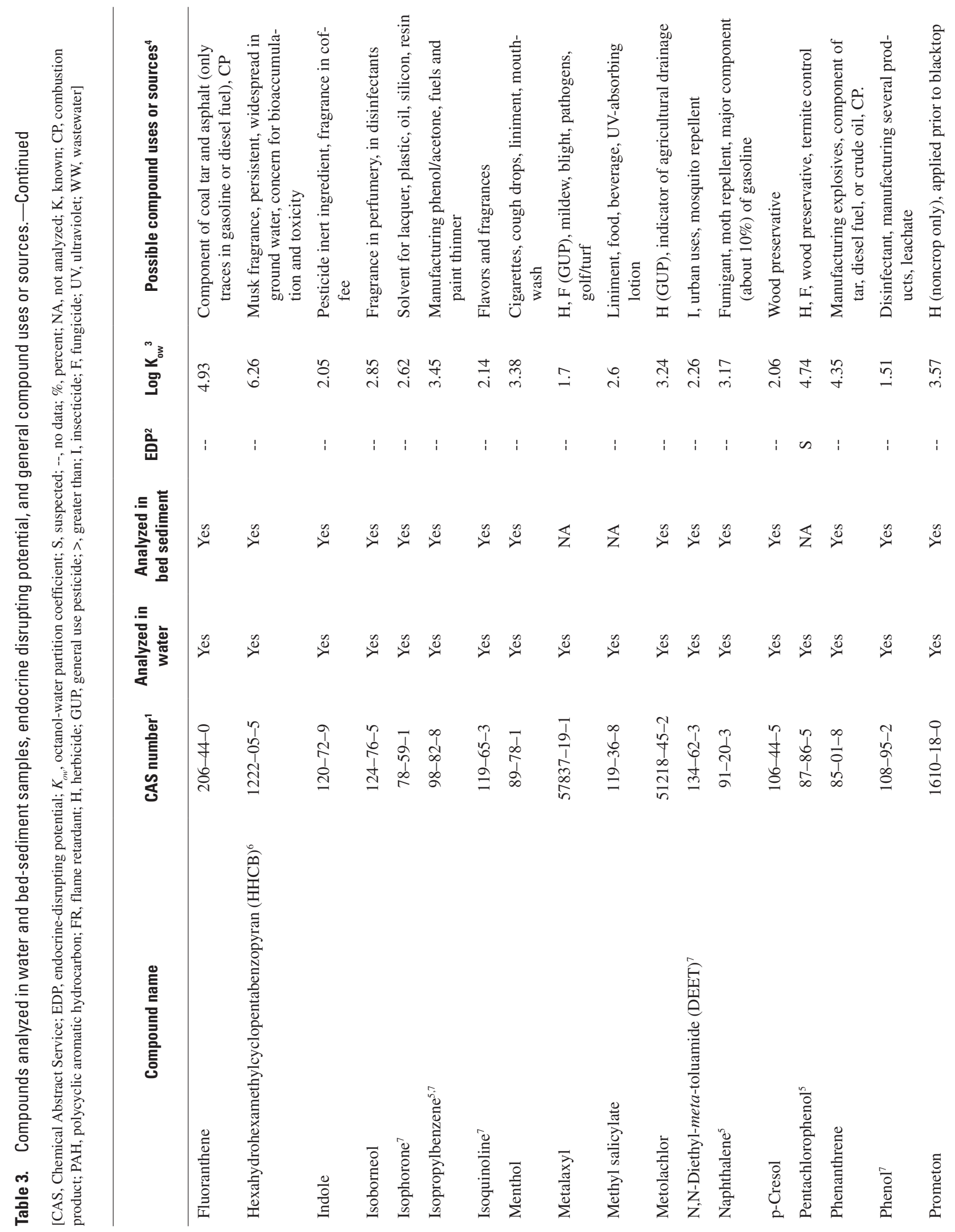




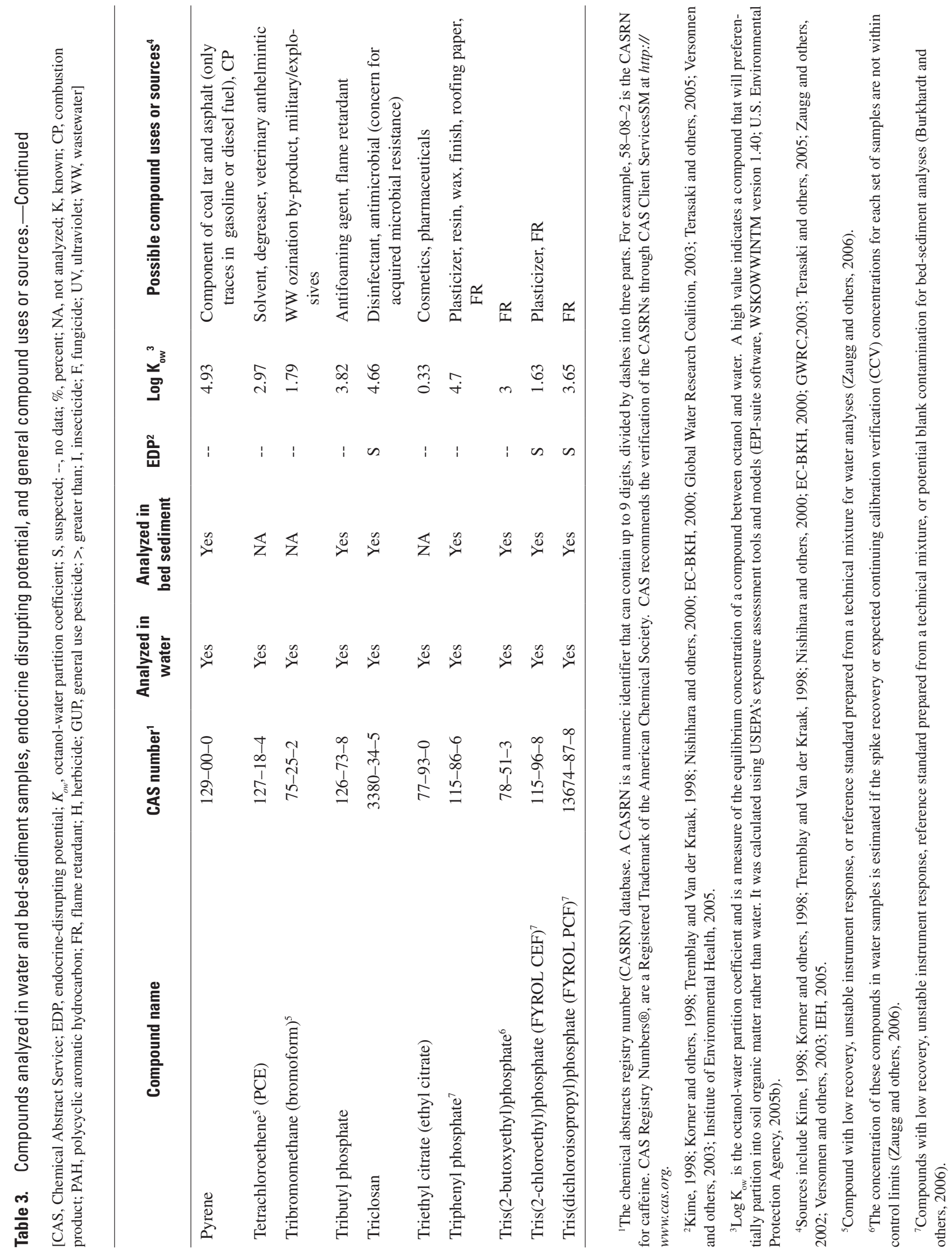


Vitellogenin concentrations were determined in fish plasma using enzyme-linked immunosorbent assay (ELISA) techniques. Whole blood samples were centrifuged in hematocrit tubes (Phoenix Research Products, Hayward, California) for 5 minutes at 12,000 revolutions per minute, and two aliquots of more than $1 \mathrm{~mL}$ plasma were retained for analyses. Triplicate aliquots from each sample were stored in two separate $-112^{\circ} \mathrm{F}$ freezers before analyses. Carp plasma samples were analyzed for vitellogenin using a commercially available carp vitellogenin ELISA kit (Biosense Laboratories, Bergen, Norway). The same kit was used for redhorse plasma and demonstrated good cross-reactivity. An ELISA antibody for striped bass was used to analyze vitellogenin concentrations in smallmouth bass plasma (Biosense Laboratories, Bergen, Norway).

Standard curves were calculated based on five to seven dilution points (after removing the highest and lowest dilution points). Each ELISA plate included two blanks and a series of purified vitellogenin standards at 250, 125, 62.5, 31.25, $15.62,7.81,3.90,1.95,0.97,0.18$, and 0.024 micrograms per milliliter $(\mu \mathrm{g} / \mathrm{mL})$. The r-square values for the standard curves were greater than 0.99 .

Testis of all male (or perceived male) fish were removed and processed for histological analysis. Histological cassettes were processed in a Jung TP1050 automated tissue processor (Leica, Wetzlar, Germany) according to an established histological protocol of dehydration and embedding in paraffin wax (Gabe, 1976). Once embedded, histological sections (three sections per histological cassette) were produced and stained with hematoxylin and eosin stains (two sections) and reticular stains (one section). Of the fish collected, 92 carp, 98 redhorse, 55 smallmouth bass, and 8 walleye were identified as being anatomically male. The reproductive condition of the fish indicated that carp were spermiating, redhorse were past reproductive activity, and smallmouth bass were nearing the end of spermiation. The slides also were examined for the occurrence of intersex. Fish were designated as intersex if microscopic evaluation determined the simultaneous occurrence of ovarian and testicular tissue (Vajda and others, 2008).

\section{Quality Assurance and Control}

The USGS National Field Manual (U.S. Geological Survey, 2003) and the Minnesota Water Science Center's Quality Assurance Plan were used to guide water- and bed-sediment data collection activities. A study quality-assurance plan was established to evaluate field sampling and laboratory techniques for water and bed sediment, to assess possible sources of contamination, and to assure that samples representative of streamflow conditions were collected. All field personnel were familiar with study design and sampling protocols before sampling or sample processing to ensure sample integrity. Laboratory quality-control samples were used to validate analytical data, and field quality-control samples were used to validate collection and processing methods.
Laboratory quality-control samples for water analyses included laboratory blanks, reagent spikes, and surrogates. Full details of the method are given in Zaugg and others (2006) and are described briefly in this report. At least one fortified laboratory spike and one laboratory blank were analyzed with each set of 10 to16 field samples. Laboratory reagent blanks were used to assess potential sample contamination. Surrogates are chemicals that have similar properties to the analytes of interest, but do not interfere with quantification of the compounds of interest. Laboratory recoveries for surrogate standards during method development, in reagent-water samples fortified at $0.5 \mu \mathrm{g} / \mathrm{L}$, averaged 72 percent plus or minus 8 percent relative standard deviation (Zaugg and others, 2006). The average recoveries were 107, 90, 63, and 91 percent respectively for the four surrogate standards (bisphenol A- $\mathrm{d}_{3}$, caffeine- ${ }^{13} \mathrm{C}_{3}$, decafluorobiphenyl, and fluoranthene- $\mathrm{d}_{10}$ ) analyzed concurrently with study samples. The concentrations of 20 compounds always were reported as estimated for one of three reasons: unacceptably low-biased recovery (less than 60 percent) or highly variable method performance (greater than 25 percent relative standard deviation); unstable instrument response; or reference standards prepared from technical mixtures (table 3). Nine additional compounds (table 3) had variable performance during the initial method validation. The concentration of these compounds was estimated if the spike recovery or expected continuing calibration verification (CCV) concentrations for each set of samples were not within control limits (Zaugg and others, 2006).

Field quality-assurance samples, including blanks and replicates, were used to assess possible bias and variability introduced during sample collection and processing of water samples. Potential contamination introduced during collection and processing was assessed with field-blank samples. Fieldblank samples were processed at selected sites before, or after, an environmental sample. Blank samples were prepared by processing high-performance, liquid chromatography grade, organic-free water through the same equipment used to collect and process field samples. Three field blank samples and three office blank samples were analyzed (appendix 1). None of the field-blank samples had detections of any compounds. This provides confidence in the effectiveness of field cleaning and sampling protocols. Two of the office-blank samples had detections of methyl salicylate at estimated concentrations of 0.0306 and $0.0062 \mu \mathrm{g} / \mathrm{L}$. Methyl salicylate is present in liniment and ultraviolet absorbing lotions.

Replicate samples were used to determine variability in detections and concentrations in water samples that resulted from sample processing and analytical techniques (sample splitting, filtration, transport, and analysis). Replicate samples consist of a split of the field sample so that the field and replicate samples should be nearly equal in composition. Replicate water samples were collected at five sites (appendix 1). Five paired (regular and replicate) samples were analyzed. Ten compounds (4-tert-octylphenol, atrazine, camphor, cholesterol, N,N-diethyl-meta-toluamide (DEET), OP2EO, hexahydrohexamethylcyclopentabenzopyran 
(HHCB), metolachlor, OP1EO, and prometon) were detected. All concentrations were present at concentrations less than method detection levels (MDLs) and thus were estimated. The MDL is the minimum concentration that can be measured and reported with a 99-percent confidence that the concentration is greater than zero (U.S. Environmental Protection Agency, 1997). Method reporting limits (MRLs) are set higher than the calculated MDLs as a precaution to reduce the risk of reporting false positives (Burkhardt and others, 2006). Atrazine was detected in 2 replicate samples, metolachlor was detected in 1 sample, and the remaining 8 compounds were each detected in 1 sample). In seven cases, detections were inconsistent, which means that a compound was detected in either the environmental or the replicate sample, but not both. For the five pairs of samples where a compound was detected in both samples, the relative percent difference $(\mathrm{RPD}=[$ Environmental concentration - Replicate concentration] / Environmental concentration) between environmental and replicate samples ranged from 1.5 to 14 , with the exception of an RPD of 120 for cholesterol. Generally, the detection consistency and non-detection consistency were acceptable given that the concentrations were less than MRLs and in many cases estimated at concentrations below the MDLs.

In addition to the routine quality-assurance schedule, three water samples were collected at each site; one was selected as the primary environmental sample, one as a duplicate, and one as a triplicate. The primary and duplicate samples were shipped to the NWQL, and the triplicate was stored in a refrigerator at the USGS Minnesota Water Science Center. These samples were collected in case of sample loss because of breakage. Before analysis, 13 primary environmental samples inadvertently were allowed to warm above proper storage temperature for less than 8 hours when a refrigerator failed at the NWQL. Because the samples had been preserved with sodium chloride before the brief warming period, the warming was not expected to affect the analytic results. As a check on data quality, however, duplicate and triplicate samples from all sites were analyzed. Analysis of the duplicate and triplicate samples generally produced more quantified results than analysis of the 41 primary samples, regardless of warming, because of updates in analytical instrumentation. Staff from the NWQL reviewed the samples for misidentified compounds, sample preparation error, potential sample mixups, and method performance. No reasons were identified to discount any of the reported analytical data (Duane Wydoski, U.S. Geological Survey, written commun., 2006, 2007).

Laboratory quality-assurance samples for bed sediment included surrogate analyses. During method development, recoveries of surrogate standards in reagent-sand samples, fortified at 4 to 72 micrograms, averaged 76 percent plus or minus 13 percent relative standard deviation for all method compounds (Burkhardt and others, 2006). The average recoveries for the three surrogate standards (bisphenol A-d ${ }_{3}$, decafluorobiphenyl, and fluoranthene- $\mathrm{d}_{10}$ ) analyzed concurrently with samples were 58, 25, and 87 percent, respectively. Initial method reporting levels for individual compounds ranged from
50 to 500 micrograms per kilogram $(\mu \mathrm{g} / \mathrm{Kg})$. The concentrations of 18 out of 59 compounds initially was reported as estimated (table 3 ) for one of four reasons: unacceptably lowbiased recovery (less than 60 percent); highly variable method performance (greater than 25 percent relative standard deviation); reference standards prepared from technical mixtures; or potential blank contamination (Burkhardt and others, 2006).

Field quality assurance for bed sediment included replicate samples. Replicate samples were prepared by splitting the bed-sediment sample into two fractions following thorough homogenization. Among the five pairs of environmental and replicate samples, 31 compounds were detected (appendix 2). Generally, the consistency of detections and non-detections between the environmental and replicate samples was greater than the incidence of inconsistent detections. There was no obvious pattern of compounds that were detected inconsistently between samples, with the exception of carbazole (2 times) and phenanthrene (3 times). Some of the compounds with inconsistent detections were detected in only one pair of samples so it is difficult to assess their consistency of detection. The site with the greatest number of inconsistent detections (site 25) was located directly downstream from the St. Paul Metropolitan WWTP. The greater variability among the replicate and environmental samples at this site may be because of the complex nature of the organic part of the bed sediment.

Replicate data also were used to assess differences between concentrations in the replicate and regular samples. The RPDs ranged from 2.1 to 1,387 percent. The median RPD among all samples was 45 percent. Differences between the replicate and regular samples may be because of the great variability in bed sediments in the environment, and that the samples were not sieved, making it difficult to achieve a consistent sample with similar bed-sediment size even after homogenization.

Because of a lack of information about EACs, attempts were made to present as much information as possible concerning the presence of these compounds in water and bed sediment. The attempt to consistently report the water or bed sediment data near the MDL is difficult, especially with the intention to transmit as much information as possible about the presence of compounds in complex samples.

The water and bed sediment analytical methods are considered to be "information-rich" (Childress and others, 1999) because compound identifications are determined by mass spectrometry; consequently, results are not censored at the MRL. Compound concentrations are reported as follows: if compound concentrations are equal or greater than the MRL or the lowest calibration standard $(0.2 \mu \mathrm{g} / \mathrm{L}$ for water and $8.0 \mu \mathrm{g} / \mathrm{kg}$ for sediment) then results are reported using three or four significant figures for water and bed sediment, respectively; if the concentrations are less than the MRL or the lowest calibration standard, then the results are reported as estimated, using an "E" code. Reporting compound results as estimated because their concentrations are less than the MRL does not decrease confidence in qualitative identification 
(Zaugg and others, 2006; Burkhardt and others, 2006). However, uncertainty is greater for concentrations reported near or less than the MDL than for concentrations greater than the MDL. When compounds are barely discernible in mass spectra and responses are near or less than the MDL, then the potential for reporting false detections (false positives) or mistakenly reporting compounds as not present (false negatives) increases. In most of these cases, when doubt about qualitative identification is considerable, reporting conservative results (that is, less than the MRL, analyte undetected) is appropriate (Zaugg and others, 2006; Burkhardt and others, 2006).

A rigorous quality-assurance protocol was followed at the SCSU Aquatic Toxicology laboratory to ensure the quality of the vitellogenin analyses and histopathology characterizations. All plasma samples were analyzed in triplicate to determine variation in test results. Coefficients of variation (standard deviation divided by the mean) were calculated to assess variation in analytical results for the veitellogenin data. The coefficients of variation were within 10 percent, which is the SCSU standard for variation. All histopathology characterizations followed U.S. Environmental Protection Agency (2006) protocols. In the field, the anterior, middle, and posterior section of testes were collected from each male fish to obtain a representative sample of the testis for histological characterization. In the laboratory, two slides of each part of the testis were made and blindly assessed according to U.S. Environmental Protection Agency (2006).

\section{Water, Bed Sediment, and Fish Data}

The environmental conditions during sampling were characterized by a prolonged dry period with little or no precipitation beginning in late June and extending through the summer. Monthly mean streamflows of the river were close to long-term averages during the months preceding sampling (January to May). During June, monthly mean streamflows at streamflow-gaging stations along the river were approximately 30 percent lower than long-term averages, and during August, mean streamflows were on average 70 percent lower than long-term averages (appendix 3).

\section{Water}

Physical measurements (dissolved oxygen, $\mathrm{pH}$, specific conductance, and water temperature) are important in the interpretation of water, bed-sediment, and biological data in rivers and streams. Each of these measurements generally increased in a downstream direction (appendix 4). Within the study area, gradients of temperature (cooler in the north), land use (less agricultural land and associated nutrient inputs in the north), and river morphology (the Mississippi River is larger and deeper in the south) exist (Stark and others, 1996). All of these spatial changes may interact and contribute to observed patterns in compound concentrations by affecting the parti- tioning, metabolism, and environmental effects of specific compounds (Hem, 1970).

Twenty-four individual compounds were detected in water samples (appendix 5). Cholesterol, atrazine, DEET, metolachlor, and HHCB were the most commonly detected compounds in water samples (in at least 10 percent of the samples). Of the alkylphenol polyethoxylates and alkylphenols (OP1EO, OP2EO, NP1EO, NP2EO, 4-cumylphenol, 4-n-octylphenol, 4-nonylphenol, and 4-tert-octylphenol), only OP1EO and OP2EO were detected in one water sample (site 7). The number of compounds detected per site ranged from 0 to 8 (fig. 2), with site number 2 (near Bemidji) having the greatest number of detections. Atrazine was detected at sites within and downstream from the TCMA (fig. 3), and DEET was detected at sites upstream from site 24 in the TCMA (fig. 4).

\section{Bed Sediment}

Forty individual compounds were detected in bedsediment samples (appendix 6). The most commonly detected compounds (in at least 50 percent of the samples) were indole, beta-sitosterol, cholesterol, beta-stigmastanol, 3-methyl-1Hindole, $p$-cresol, pyrene, phenol, fluoranthene, and 3-beta coprostanol, benzo[a]pyrene, acetophenone, and 2,6-dimethylnaphthalene. The total number of detections in bed sediment (at a site) ranged from 3 to 31 and was greatest at site 2 near Bemidji (fig. 5). Detections of alkylphenol polyethoxylates and alkylphenols (OP1EO, OP2EO, NP1EO, NP2EO, 4-cumylphenol, 4-n-octylphenol, 4-nonylphenol, and 4-tertoctylphenol) ranged from 0 to 5 in bed-sediment samples (fig. 6). The compounds NP1EO, NP2EO, and 4-nonylphenol were detected in greater than 10 percent of the samples.

\section{Fish}

Most (75 percent) female fish collected had measurable concentrations of vitellogenin. Female carp generally had greater plasma vitellogenin concentrations $(1.53-248,079$ $\mu \mathrm{g} / \mathrm{mL}$ ) than females of the three other species (less than detection - 17,434 $\mu \mathrm{g} / \mathrm{mL}$ ) (appendix 7). Vitellogenin also was detected in 62,63, and 33 percent of male carp, smallmouth bass, and redhorse, respectively. The one male walleye sample analyzed had a vitellogenin detection. Vitellogenin concentrations were lower in male fish (less than detection -10.80 $\mu \mathrm{g} / \mathrm{mL}$ ) than female fish (0.04 to $248,079 \mu \mathrm{g} / \mathrm{mL}$ ). Gonadosomatic Index values ranged from 0.02 to 7.49 percent among all male fish, and were greater for male carp than for the other three species. No intersex was present in any male fish. 


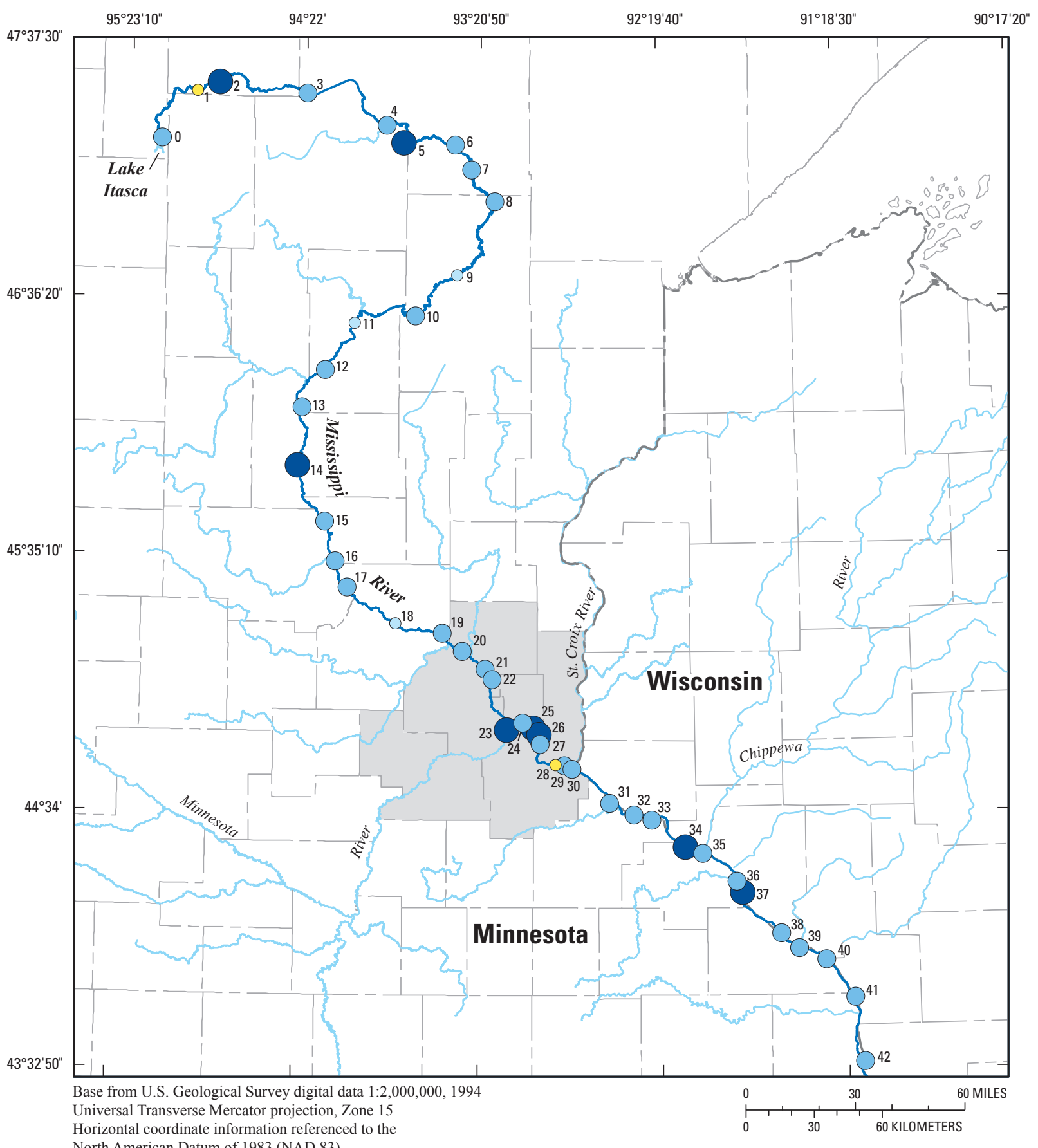

EXPLANATION

Minneapolis/St. Paul metropolitan area
Compounds detected in water sample-
Number is site identifier. Yellow dot indicates
site not sampled
None detected
1 to 3
4 to 8

Figure 2. Number of wastewater indicator compounds detected in water samples. 


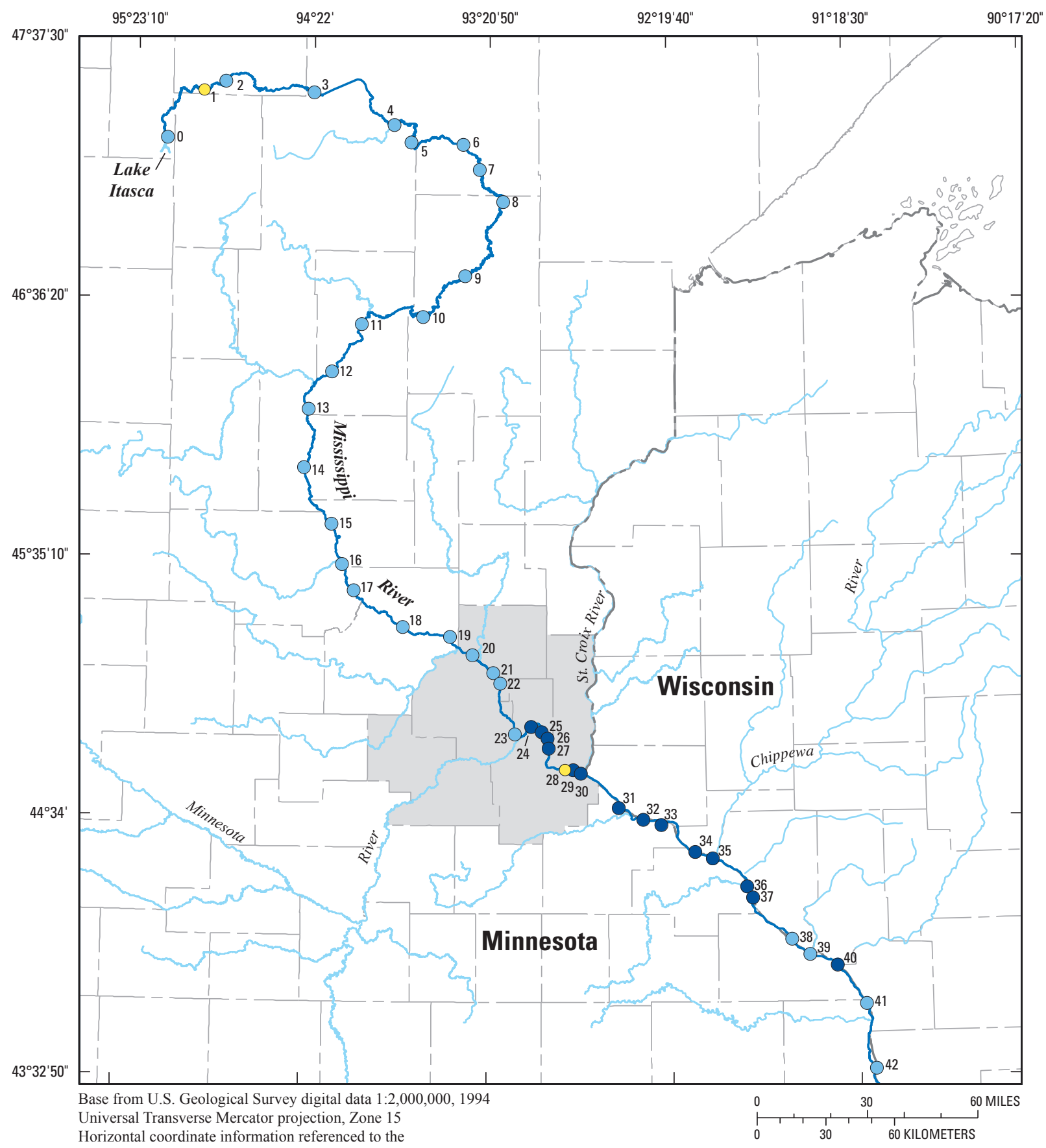

EXPLANATION

Minneapolis/St. Paul metropolitan area

Atrazine detections in water sample-

Number is site identifier. Yellow dot indicates

site not sampled

Non detection

Detection

Figure 3. Atrazine detections in water samples. 


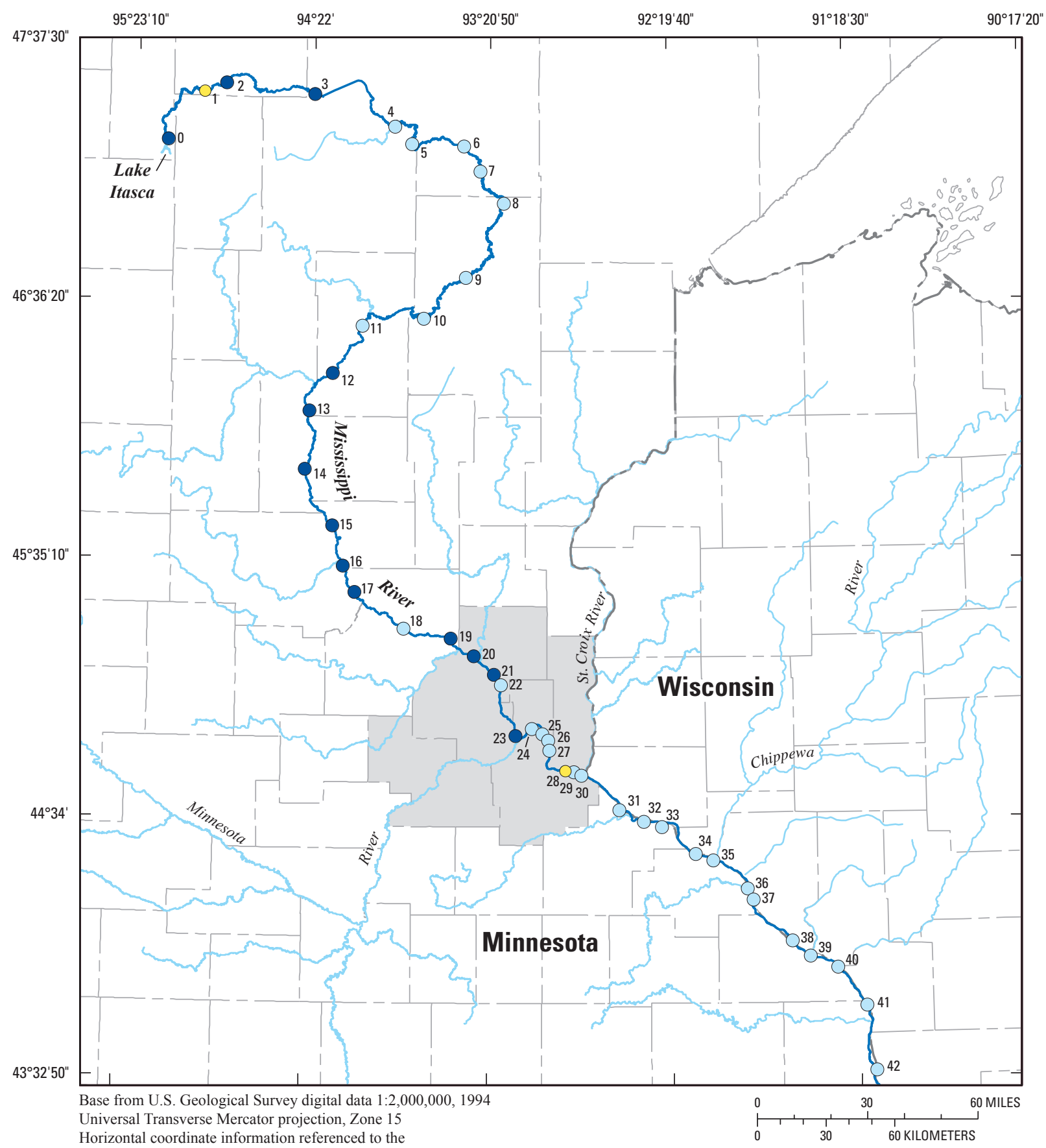

North American Datum of 1983 (NAD 83)

EXPLANATION

Minneapolis/St. Paul metropolitan area

DEET detections in water sample-

Number is site identifier. Yellow dot indicates

site not sampled

Non detection

Detection

Figure 4. N,N-diethyl-meta-toluamide (DEET) detections in water samples. 


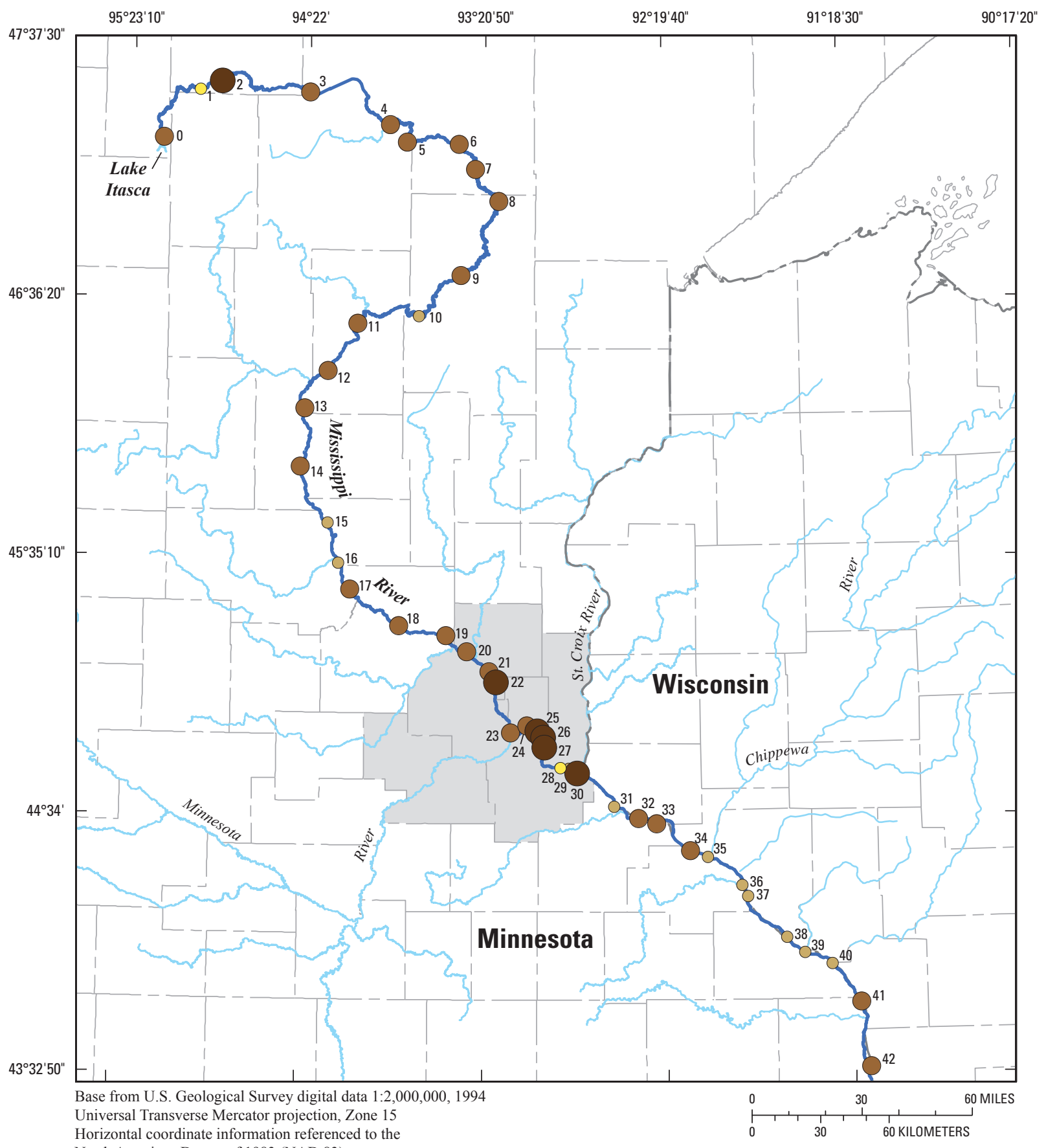

(the

North American Datum of 1983 (NAD 83)

EXPLANATION

Minneapolis/St. Paul metropolitan area

Compounds detected in bed-sediment sample-

Number is site identifier. Yellow dot indicates

site not sampled

1 to 10

11 to 20

21 to 31

Figure 5. Number of wastewater indicator compounds detected in bed-sediment samples. 


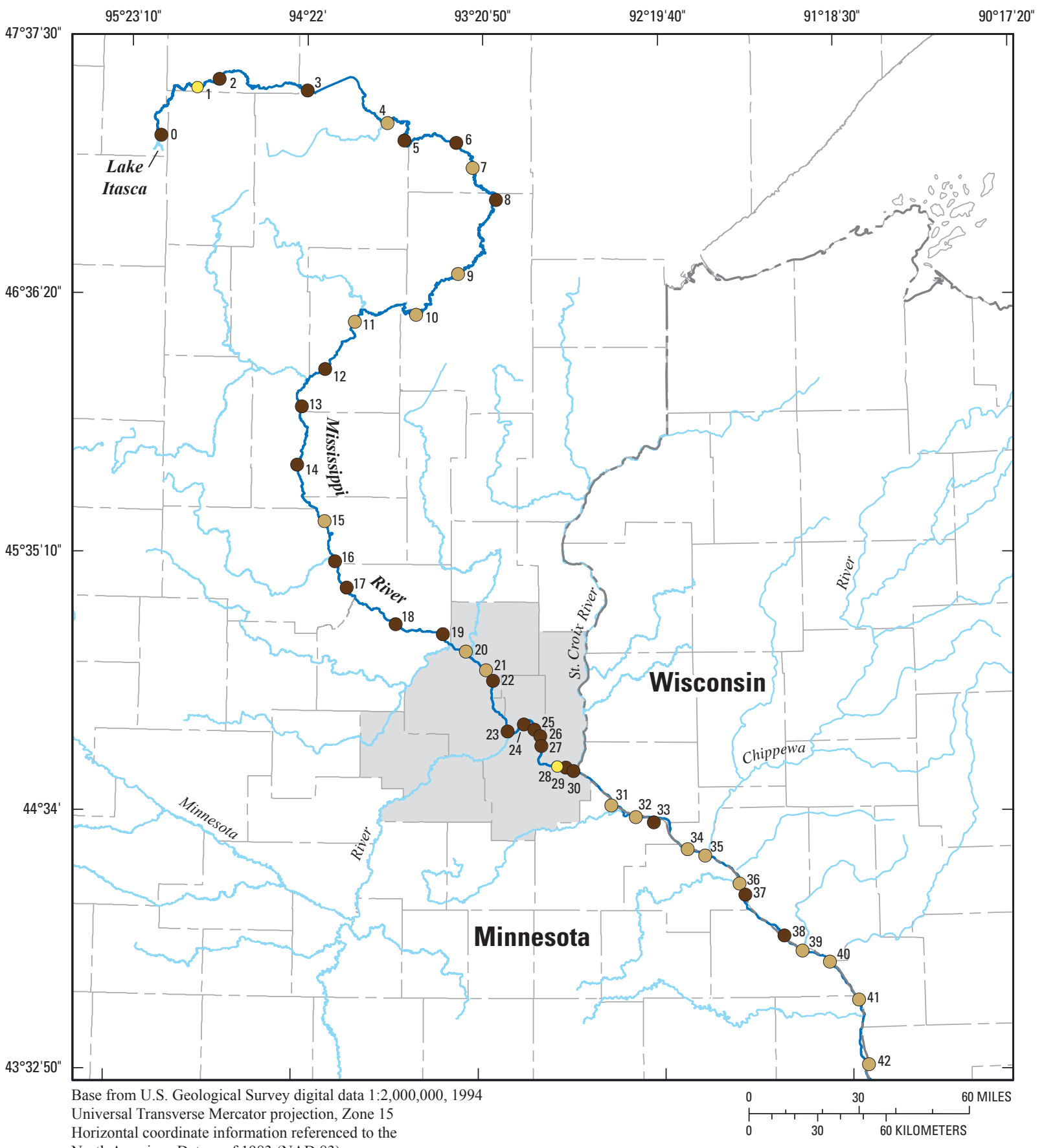

EXPLANATION

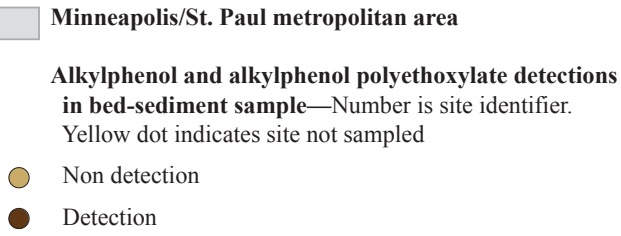

Figure 6. Alkylphenol and alkylphenol polyethoxylate detections in bed-sediment samples. 


\section{Summary}

Concern that selected chemicals in the environment may act as endocrine active compounds (EACs) in aquatic ecosystems is widespread; however, few studies have examined the occurrence of EACs and identified biological markers of endocrine disruption such as intersex occurrence in fish. EACs interfere with the natural regulation of endocrine systems by either mimicking or blocking the function of natural hormones. This interference commonly is referred to as endocrine disruption. Although factors contributing to endocrine disruption in fish are complex, laboratory studies have confirmed that EACs, such as hormones and alkylphenols (a class of surfactants that includes nonylphenol), affect the endocrine systems of fish through biochemical, structural, and behavioral mechanisms. Wastewater treatment plant effluent has been identified as a primary pathway of EACs to the aquatic environment (Desbrow and others, 1998; Ternes and others, 1999; Johnson and Sumpter, 2001).

Because little integrated information is available about endocrine disruption and causative factors in field studies, the U.S. Geological Survey (USGS), in cooperation with the Minnesota Pollution Control Agency (MPCA) and St. Cloud State University (SCSU), initiated an integrated biological and chemical study of the Mississippi River in Minnesota to build on previous research. Objectives of the study were to collect water, bed sediment, and fish at 43 sites along the Mississippi River from the headwaters at Lake Itasca to 14 miles downstream from Brownsville, Minnesota, from June through August 2006.

Twenty-four individual compounds were detected in water samples, with cholesterol, atrazine, N,N-diethyl-metatoluamide, metolachlor, and hexahydrohexamethylcyclopentabenzopyran detected most frequently (in at least 10 percent of the samples). The number of compound detections in water (at a site) ranged from 0 to 8 .

Forty individual compounds were detected in bed-sediment samples. The most commonly detected compounds (in at least 50 percent of the samples) were indole, beta-sitosterol, cholesterol, beta-stigmastanol, 3-methyl-1H-indole, $p$-cresol, pyrene, phenol, fluoranthene, and 3-beta coprostanol, benzo[a] pyrene, acetophenone, and 2,6-dimethylnaphthalene. The total number of detections in bed sediment (at a site) ranged from 3 to 31 . The compounds NP1EO, NP2EO, and 4-nonylphenol were detected in greater than 10 percent of the samples.

Most (80 percent) female fish collected had measurable concentrations of vitellogenin. Vitellogenin also was detected in 62,63 , and 33 percent of male carp, smallmouth bass, and redhorse, respectively. The one male walleye plasma sample analyzed had a vitellogenin detection. Vitellogenin concentrations were lower in male fish (not detected - $10.80 \mu \mathrm{g} / \mathrm{mL}$ ) than female fish $(0.04$ to $248,079 \mu \mathrm{g} / \mathrm{mL})$. Gonadosomatic Index values ranged from 0.02 to 7.49 percent among all male fish and were greater for male carp than for the other three species. No intersex (oocytes present in the testes) was present in any male fish sampled.

The study was designed to identify patterns of occurrence and distribution of selected organic chemicals including endocrine active compounds and to relate those patterns to intersex characteristics and other biomarkers of endocrine disruption in four species of fish. The study provides information to compare with previous studies measuring intersex occurrence in fish in the river and helps define the spatial distribution of endocrine disruption in the river.

\section{Selected References}

Allen, Y., Scott, A.P., Matthiessen, P., Haworth, S., Thain, J.E., and Feist, S., 1999, Survey of estrogenic activity in United Kingdom estuarine and coastal waters and its effects on gonadal development of the flounder Platichthys flesus: Environmental Toxicology and Chemistry, v. 18, no. 8, p. $1,791-1,800$.

Ankley, G., Francis, E., Gray, E., Kavlock, R., McMaster, S., Reese, D., Sayles, G., Sergeant, A. and Vallero, D., 1998, Research plan for endocrine disruptors: Research Triangle Park, N.C., Office of Research and Development, U.S. Environmental Protection Agency, EPA600/R-98/087, 47 p.

Barber, L.B., Brown, G.K., and Zaugg, S.D., 2000, Potential endocrine disrupting organic chemicals in treated municipal wastewater and river water, in Keith, L.H., Jones-Lepp, T.L., and Needham, L.L., eds., Analysis of environmental endocrine disruptors: Washington D.C., American Chemical Society Symposium Series 747, p. 97-123.

Barber, L.B., Lee, K.E., Swackhammer, D.L., and Schoenfuss, H.L., 2007, Reproductive responses of male fathead minnows exposed to wastewater treatment plant effluent, effluent treated with XAD8 resin, and an environmentally relevant mixture of alkylphenol compounds: Aquatic Toxicology, v. 82, p. 36-46.

Bistodeau, T.J., Barber, L.B., Bartell, S.E., Cediel, R.A., Grove, K.J., Klaustermeier, Jacob, Woodard, J.C., Lee, K.L., and Schoenfuss, H.L., 2006, Larval exposure to environmentally relevant mixtures of alkylphenolethoxylates reduces reproductive competence in male fathead minnows: Aquatic Toxicology, v. 79, p. 268-277.

Buerge, I.J., Buser, H., Muller, M.D., and Poiger, T., 2003, Behavior of the polycyclic musks HHCB and AHTN in lakes, two potential anthropogenic markers for domestic wastewater in surface waters: Environmental Science and Technology, v. 37, no. 24, p. 5,636-5,644. 
Burkhardt, M.R., Zaugg, S.D., Smith, S.G., and ReVello, R.C., 2006, Determination of wastewater compounds in sediment and soil by pressurized solvent extraction, solid-phase extraction, and capillary-column gas chromatography/ mass spectrometry: U.S. Geological Survey Techniques and Methods, book 5, chap. B2, 90 p.

Childress, C.J.O., Foreman, W.T., Connor, B.F., and Maloney, T.J, 1999, New reporting procedures based on longterm method detection levels and some considerations for interpretations of water-quality data provided by the U.S. Geological Survey National Water Quality Laboratory: U.S. Geological Survey Open-File Report 99-193, 19 p.

Colburn, T., and Clement, C., 1992, Chemically induced alterations in sexual and functional development-The wildlife/ human connection: Princeton, N.J., Princeton Scientific Publishing, $403 \mathrm{p}$.

Desbrow, C., Routledge, E.J., Brighty, G.C., Sumpter, J.P., and Waldock, M., 1998, Identification of estrogenic chemicals in STW effluent-1. Chemical fractionation and in vitro biological screening: Environmental Science and Technology, v. 32, p. 1,549-1,558.

EC-BKH, 2000, Towards the establishment of a priority list of substances for further evaluation of their role in endocrine disruption (final report): Delft, The Netherlands, BKH Consulting Engineers, European commission DG ENV, accessed July 14, 2008, at http://ec.europa.eu/environment docum/01262_en.htm

EXtension TOXicology NETwork, 2006, EXTOXNET InfoBase, accessed January 17, 2006, at http://ace.orst.edu infolextoxnet

Folmar, L.C., Denslow, N.D., Rao, V., Chow, M., Crain, D.A., Enblom, J., Marcino, J., and Guillette, L.J., Jr., 1996, Vitellogenin induction and reduced serum testosterone concentrations in feral male carp (Cyprinus carpio) captured near a major metropolitan sewage treatment plant: Environmental Health Perspectives, v. 104, no. 10, p. 1,096-1,101.

Folmar, L.C. Denslow, N.D., Kroll, K., Orlando, E.F., Enblom, J., Marcino, J., Metcalfe, C., and Guillette, L.J., Jr., 2001, Altered serum sex steroids and vitellogenin induction in walleye (Stizostedion vitreum) collected near a metropolitan sewage treatment plant: Archives of Environmental Contamination Toxicology, v. 40, p. 392-398.

Gabe, Manfred, 1976, Histological techniques: New York, Springer-Verlag, 1,106 p.

Goldstein, R.M., Lee, K.E., Talmage, P.J., Stauffer, J.C., and Anderson, J.P., 1999, Relation of fish community composition to environmental factors and land use in part of the Upper Mississippi River Basin, 1995-97: U.S. Geological Survey Water-Resources Investigations Report 99-4034, $32 \mathrm{p}$.
Global Water Research Coalition, 2003, Endocrine disrupting compounds, priority list of EDCs, September 2003: London, Global Water Research Coalition, 29 p.

HealthCentral.com, 2006, RxList, the internet drug index, accessed January 17, 2006, at http://www.rxlist.com

Hem, John David, 1970, Study and interpretation of the chemical characteristics of natural water: U.S. Geological Survey Water Supply Paper, 363 p.

Institute for Environmental Health, 2005, Chemicals purported to be endocrine disrupters-A compilation of published lists: Leicester, UK, MRC Institute for Environment and Health, Web Report W20, accessed July 13, 2008, at http:// www.silsoe.cranfield.ac.uk/ieh/pdf/w20.pdf

Johnson, A.C., and Sumpter, J.P., 2001, Removal of endocrinedisrupting chemicals in activated sludge treatment works: Environmental Science and Technology, v. 35, p. 4,697-4,703.

Kime, D.E., 1998, Endocrine disruption in fish: Boston, Mass., Kluwer Academic Publishers, 396 p.

Korner, W., Hanf, V., Schuller, W., Bartsch, H., Zwirner, M., and Hagenmaier, H, 1998, Validation and application of a rapid in vitro assay for assessing the estrogenic potency of halogenated phenolic chemicals: Chemosphere, v. 37 p. 2,395-2,407.

Kroening, S.E., Fallon, J.D., and Lee, K.E., 2000, Water-quality assessment of part of the Upper Mississippi River Basin, Minnesota and Wisconsin-Trace elements in streambed sediment and fish livers, 1995-96: U.S. Geological Survey Water-Resources Investigations Report 00-4031, 26 p.

Lee, K.E., Blazer, V.S., Denslow, N.D., Goldstein, R.M., and Talmage, P.J., 2000, Use of biological characteristics of common carp (Cyprinus carpio) to indicate exposure to hormonally active agents in selected Minnesota streams, 1999: U.S. Geological Survey Water-Resources Investigations Report 00-4202, 47 p.

Lee, K.E., and Blazer, V., 2005, Endocrine disruption in Minnesota fish-A comparison of fish species, Cyprinus carpio and Micropterus: Madison, Wis., Society of Environmental Toxicology and Chemistry, v. 136, p. 381-388.

Minnesota Pollution Control Agency, 2000, Upper Mississippi River Basin information document: St. Paul, Minn., Minnesota Pollution Control Agency, p. 11-40, accessed June 10, 2008, at http://www.pca.state.mn.us/water/basins/ uppermiss/bid-uppermiss.pd].

National Institute of Standards and Technology, 2006, NIST chemistry webBook, accessed January 17, 2006, at http:// webbook.nist.gov 
National Research Council, 1999, Hormonally active agents in the environment: Washington, D.C., National Academy Press, $429 \mathrm{p}$.

National Toxicology Program, 2006, Chemical health and safety data, accessed March 22, 2006, at http://ntp.niehs. nih.gov

Nishihara, T., Nishikawa, J., Hori, S., Saito, K., Kanayama, T., Imagawa, M., Takatori, S., Kitagawa, K., Dakeyama, F., and Utsumi, H., 2000, Oestrogenic activities of 517 chemicals by yeast two-hybrid assay: Journal of Health Sciences, v. 46, p. 282-298.

Payne, G.A., 1994, Sources and transport of sediment, nutrients, and oxygen-demanding substances in the Minnesota River Basin, 1989-92: U.S. Geological Survey WaterResources Investigations Report 93-4232, 71 p.

Schoenfuss, H.L., 2003, The need for novel approaches in assessing the biological impact of biologically active compounds in Masters, R., ed., Proceedings of the 3rd International Conference on Pharmaceuticals and Endocrine Disrupting Chemicals in Water, Minneapolis, Minn., March 19-21, 2003: National Ground Water Association, p. $103-121$.

Schoenfuss, H.L., Bartell, S.E., Bistodeau, T.B., Cediel, R.A., Grove, K.J., Zintek, L., Lee, K.E., Barber, L.B., 2008, Impariment of the reproductive potential of male fathead minnows by environmentally relevant exposures to 4-nonylphenol: Aquatic Toxicology, v. 86, p. 91-98.

Spectrum Laboratories Inc., 2006, Compound list, accessed January 17, 2006, at http://www.speclab.com/compound chemabc.htm

Stark, J.R., Andrews, W.J., Fallon, J.D., Fong, A.L., Goldstein, R.M., Hanson, P.E., Kroening, S.E., and Lee, K.E., 1996, Water-quality assessment of the Upper Mississippi River Basin Study Unit, Minnesota and Wisconsin-Environmental setting and study design: U.S. Geological Survey WaterResources Investigations Report 96-4098, 62 p.

Ternes, T.A., Stumpf, M., Mueller, J., Haberer, K., Wilken, R.D., Servos, M., 1999, Behavior and occurrence of estrogens in municipal sewage treatment plants-I. Investigations in Germany, Canada, and Brazil: Science of the Total Environment. v. 225, no. 1-2, p. 81-90.

Terasaki M., Shiraishi F., Nishikawa T., Edmonds J.S., Morita M., and Makino, M. 2005, Estrogenic activity of impurities in industrial grade bisphenol A: Environmental Science and Technology, v. 39, no. 10, p. 3, 703-707.
Tremblay, L., and Van der Kraak, G., 1998, Use of a series of homologous in vitro and in vivo assays to evaluate the endocrine modulating actions of b-sitosterol in rainbow trout: Aquatic Toxicology, v. 43, p. 149-162.

Underhill, J.C., 1989, The distribution of Minnesota fishes and late Pleistocene glaciation: Journal of the Minnesota Academy of Sciences, v. 55, p. 32-37.

U.S. Environmental Protection Agency, 1997, Guidelines establishing test procedures for the analysis of pollutants (Appendix B to part 136, Definition and procedure for the determination of the method detection limit): U.S. code of Federal regulations, Title 40, revised as of July 1, 1997, p. 265-267.

U.S. Environmental Protection Agency, 2005a, Ambient aquatic life water quality criteria for nonylphenol-final: Washington, D.C., U.S. Environmental Protection Agency EPA/822-R-05-005.

U.S. Environmental Protection Agency. 2005b, Estimation Program Interface (EPI) suite, accessed January 12, 2006, at www.epa.gov/opptintr/exposure/pubs/episuite.htm

U.S. Environmental Protection Agency, 2006, Histopathology guidelines for the fathead minnow (Pimephales promelas) 21-day reproduction assay, accessed June 20, 2008, at http:// www.epa.gov/endo/pubs/att-h_histopathologyguidlines_fhm. pdd

U.S. Geological Survey, 2003, National field manual for the collection of water-quality data: U.S. Geological Survey Techniques of Water-Resources Investigations, book 9, variously paged, available online at http://water.usgs.gov/owq FieldManual

Vajda, A.M., Barber, L.B., Gray, J.L., Lopez, E.M., Woodling, J.D., Norris, D.O., 2008, Reproductive disruption in fish downstream from an estrogenic wastewater effluent: Environmental Science and Technology, v. 42, p. 3,407-3,414.

Versonnen, B.J., Arijs, K., Verslycke, T., Lema, W., and Janssen, C.R., 2003, In vitro and in vivo estrogenicity and toxicity of $o-, m-$, and $p$-dichlorobenzene: Environmental Toxicology and Chemistry, v. 22, no. 2, p. 329-335.

Wiener, J.G., Jackson, G.A., May, T.W., and Cole, B.P., 1984, Longitudinal distribution of trace elements (As, Cd, Cr, Hg, $\mathrm{Pb}$, and $\mathrm{Se}$ ) in fishes and sediments in the Upper Mississippi River, in Wiener, J.G., Anderson, R.V., and McConville, D.R., eds., Contaminants in the Upper Mississippi River, Proceedings of the 15th Annual Meeting of the Mississippi River Research Consortium, La Crosse, Wis., April 14-15, 1982: Stoneham, Mass., Butterworth Publishers, p. 139-170. 
Zaugg, S.D., Smith, S.G., Schroeder, M.P., Barber, L.B., and Burkhardt, M.R., 2002, Methods of analysis by the U.S. Geological Survey National Water-Quality LaboratoryDetermination of wastewater compounds by polystyrenedivinylbenzene solid-phase extraction and capillary-column gas chromatography/mass spectrometry: U.S. Geological Survey Water-Resources Investigations Report 01-4186, $37 \mathrm{p}$.

Zaugg, S.D., Smith, S.G., and Schroeder, M.P., 2006, Determination of wastewater compounds in whole water by continuous liquid-liquid extraction and capillary-column gas chromatography/mass spectrometry: U.S. Geological Survey Techniques and Methods, book 5, chap. B4, 30 p.

Zhang, F., Bartels, M.J., Brodeur, J.C., and Woodburn, K.B., 2004, Quantitative measurement of fathead minnow vitellogenin by liquid chromatography combined with tandem mass spectrometry using a signature peptide of vitellogenin: Environmental Toxicology and Chemistry, v. 23, p. $1,408-1,415$. 



\section{Appendixes 1-7}

Appendix 1. The Excel spreadsheet Appendix-1.xls contains concentration data for
compounds in quality-assurance samples of water submitted in 2006 as part of this study.
Quality-assurance samples included in the spreadsheet are blanks, replicates, and spikes.

Appendix 2. The Excel spreadsheet Appendix-2.xls contains concentration data for compounds in bed sediment quality-assurance samples submitted in 2006 as part of this study. Quality-assurance samples included in the spreadsheet are replicates.

Appendix 3. The Excel spreadsheet Appendix-3.xls contains streamflow statistics for selected sampling sites. Monthly statistics are presented for 2006 and for the period of record for the selected sites. Data used to generate the statistics are available from http://waterdata. usgs.gov/mn/nwis/sw

Appendix 4. The Excel spreadsheet Appendix-4.xls contains data on physical measurements of water quality for samples collected in 2006. Physical measurements of dissolved oxygen, $\mathrm{pH}$, specific conductance, and water temperature are included in the spreadsheet.

Appendix 5. The Excel spreadsheet Appendix-5.xls contains concentration data for organic compounds analyzed in water samples for this study. Results of water samples collected from 41 sites during June through August 2006 are included in the spreadsheet.

Appendix 6. The Excel spreadsheet Appendix-6.xls contains concentration data for organic compounds analyzed in bed sediment for this study. Results of water samples collected from 41 sites during June through August 2006 are included in the spreadsheet.

Appendix 7. The Excel spreadsheet Appendix-7.xls contains biological characteristics of fish collected for this study. Results of fish samples collected from 38 sites during June through August 2006 are included in the spreadsheet. 
Publishing support provided by:

Rolla Publishing Service Center

For more information concerning this publication, contact: Director, USGS Minnesota Water Science Center

2280 Woodale Drive

Mounds View, Minnesota 55112

(763) 783-3100

Or visit the Minnesota Water Science Center Web site at: http://mn.water.usgs.gov 

